(revised manuscript)

\title{
Recent advances in the use of glycerol as green solvent for synthetic organic chemistry
}

\author{
Alba E. Díaz-Álvarez, Javier Francos, Pascale Crochet and Victorio Cadierno* \\ Laboratorio de Compuestos Organometálicos y Catálisis (Unidad Asociada al CSIC), \\ Departamento de Química Orgánica e Inorgánica, IUQOEM, Facultad de Química, \\ Universidad de Oviedo, Julián Clavería 8, E-33006 Oviedo, Spain
}

\begin{abstract}
Owing to its biodegradable and non-toxic nature, glycerol, the main byproduct in the production of biodiesel fuel, is being actively investigated as a green reaction medium for synthetic organic chemistry. A huge number of synthetic transformations have been conducted in glycerol in recent years, showing most of them similar or even superior efficiency and selectivity than those performed in conventional petroleum-based organic solvents. Herein, an overview on the most recent advances reached in the field is presented.
\end{abstract}

Short Running Title: Synthetic organic chemistry in glycerol

Keywords: Glycerol; Green solvent; Promoting medium; Hydrogen donor; Organic synthesis; Homogeneous catalysis; Biocatalysis.

* Address correspondence to this author at the Departamento de Química Orgánica e Inorgánica, Facultad de Química, Universidad de Oviedo, Julián Clavería 8, E-33006 Oviedo, Spain; Tel: +34 9851034 53; Fax: +349851034 46. E-mail: vcm@uniovi.es 


\section{Introduction}

The development of Green Chemistry and the search for cleaner synthetic methods are of utmost importance in organic chemistry, especially for the chemical industry [1-9]. In this context, the use of eco-friendly solvents is particularly recommended because the majority of waste and pollution generated by the chemical processes is directly related to solvents (it has been estimated that $80-90 \%$ of mass utilization in a chemical transformation is due to the solvents employed) [10-12]. With the ultimate goal of solving this environmental problem, several alternatives for the replacement of traditional organic solvents (most of them derived from petroleum and having negative environmental, health and safety impacts) have been evaluated during the last years (water, ionic liquids, supercritical fluids, perfluorinated solvents, etc.) [13-15]. In particular, given its great availability and non-toxic nature, the use of water as alternative "green solvent" in synthetic organic chemistry is being widely investigated [16-22], but the subsequent production of wastewater should not be underestimated.

In the continuous search for eco-friendly solvents, biomass-derived chemicals are also emerging as very promising alternatives [23-26]. Among them, glycerol is attracting considerable attention since the fast development of the biodiesel industries, in which it is formed as the main byproduct, has generated a large excess of this chemical (ca. $100 \mathrm{~kg}$ of glycerol per ton of biodiesel are formed) (Scheme 1). In fact, recent studies have estimated that world-wide production of glycerol in 2010 was about 2 million tons [27]. In addition, it is expected that this quantity will increase in the future due to the growing demand for biodiesel, as well as the rapid development of other processes based on the conversion of cellulose and lignocelluloses into value-added chemicals in which glycerol is also generated as byproduct. Consequently, new applications for this low-cost raw material are needed [28]. According to the Green Chemistry principles, glycerol is a prototypical example of a "green solvent" [1]. In fact, as suggested by Jérôme and co-workers [29], glycerol can be considered as "organic water" since, like water, it is abundant, biodegradable, inexpensive, 
non-toxic, highly polar, immiscible with hydrocarbons, able to form strong hydrogen-bond networks and able to dissolve a wide range of organic and inorganic compounds, including transition metal catalysts. In addition, compared to water, it has the advantage of its higher boiling point, lower vapor pressure, and that it is able to dissolve organic compounds usually immiscible with water. The possibility of revalorize glycerol using it as a solvent for synthetic chemistry has been very well received by the chemical community, as clearly demonstrated by the large number of stoichiometric and catalytic organic reactions that have been successfully performed in this medium in recent years [30-35]. Remarkably, the use of glycerol as solvent has resulted in some cases in an enhanced reactivity and/or selectivity, and also in an easier product separation and an improved catalyst recycling.

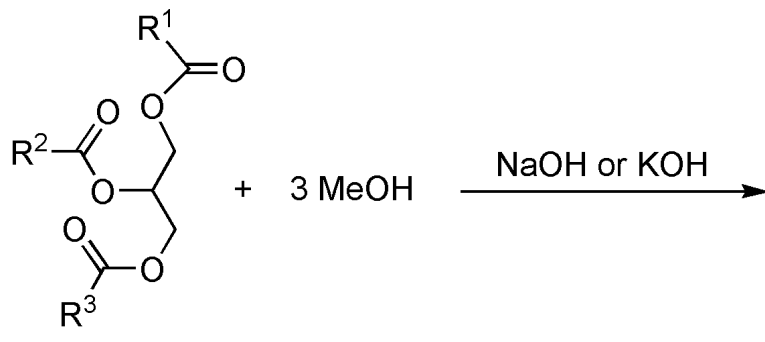

Triglycerides

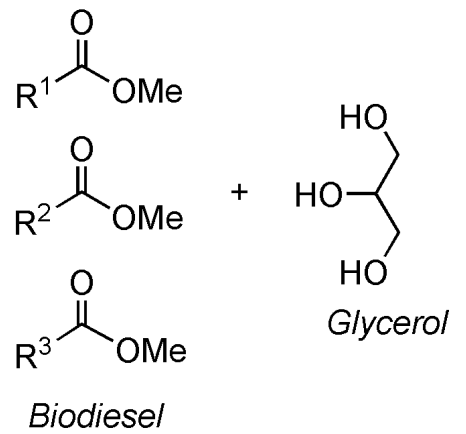

$\mathrm{R}^{1}, \mathrm{R}^{2}, \mathrm{R}^{3}=$ hydrocarbon chain from 15 to 21 carbon atoms

Scheme 1. General reaction involved in the production of biodiesel.

In 2011 we published a comprehensive review article covering the use of glycerol as solvent in organic synthesis [31]. Herein, an update with the most recent advances reached in the field is presented. Literature published between March 2011 and April 2013 is covered. Transformations of glycerol into other chemicals are considered out of the scope of this review.

\section{Metal-free transformations}


First examples on the use of glycerol as solvent for synthetic organic chemistry were published by Wolfson's group in 2007, who successfully accomplished the nucleophilic substitution of benzyl chloride $(\mathrm{BnCl})$ with $\mathrm{KSCN}$, and the reduction of benzaldehyde with sodium borohydride, in this "green" reaction medium [36]. In this line, the same group has recently studied the nucleophilic substitution of $\mathrm{BnCl}$ and $\mathrm{BnBr}$ with ammonium and sodium acetate [37-38]. As a solvent, glycerol facilitated the solubility of both the organic substrates and salts, thus avoiding the use of phase transfer agents, and it enabled the easy isolation of the benzyl acetate product by selective extraction with hexanes or diethyl ether. Easy separation of the reaction product, i.e. benzyl alcohol or ethanol, along with an effective catalyst recycling, was also observed by Wolfson's group and others while studying the transesterification of benzyl and ethyl acetate in glycerol catalyzed by different bases [39-40] and acids [41]. In these reactions, glycerol acted both as solvent and acyl acceptor.

A clean and fast methodology for the synthesis of organic disulfides in glycerol was presented by Lenardão and Jacob in 2012 (Scheme 2) [42]. The process, which is promoted by $\mathrm{Na}_{2} \mathrm{CO}_{3}$ under microwave irradiation (MW), was operative with aliphatic, aromatic and heteroaromatic thiols, leading to the corresponding disulfides in very good yields. After extraction of the products with a mixture of hexane/ethyl acetate, the glycerol employed could be recovered and reused in subsequent reactions (up to five consecutive runs).

$$
\begin{aligned}
& \mathrm{RSH} \underset{\mathrm{Na}}{\stackrel{\mathrm{Na}_{2} \mathrm{CO}_{3}(1.1 \text { equiv. }) / \text { glycerol }}{120^{\circ} \mathrm{C} / \mathrm{MW}(100 \text { watts }) / 15 \mathrm{~min}}} 1 / 2 \mathrm{RS}-\mathrm{SR} \\
& \text { (81-93\% yield) } \\
& \mathrm{R}={ }^{\mathrm{n}} \mathrm{Pr},{ }^{\mathrm{t}} \mathrm{Bu}, n-\mathrm{C}_{8} \mathrm{H}_{17}, \mathrm{CH}_{2} \mathrm{OH}, \mathrm{Ph}, \mathrm{Bn}, 2 \text { 2-naphthyl, 2- } \mathrm{C}_{6} \mathrm{H}_{4} \mathrm{Me} \text {, } \\
& \text { 3- } \mathrm{C}_{6} \mathrm{H}_{4} \mathrm{Me}, 4-\mathrm{C}_{6} \mathrm{H}_{4} \mathrm{Me}, 4-\mathrm{C}_{6} \mathrm{H}_{4} \mathrm{OMe}, 2-\mathrm{NH}_{2}-4-\mathrm{C}_{6} \mathrm{H}_{3} \mathrm{Cl} \text {, } \\
& \text { 4- } \mathrm{C}_{6} \mathrm{H}_{4} \mathrm{~F}, 2-\mathrm{C}_{6} \mathrm{H}_{4} \mathrm{Cl}, 4-\mathrm{C}_{6} \mathrm{H}_{4} \mathrm{Cl}, 4-\mathrm{C}_{6} \mathrm{H}_{4} \mathrm{Br}, \mathrm{CH}_{2} \text {-2-furyl }
\end{aligned}
$$

Scheme 2. Base-promoted synthesis of disulfides in glycerol.

The same group has also developed an effective protocol for the preparation of 2organoselanyl pyridines 2 by reaction of 2-chloropyridines 1 with organylselenols $\left(\mathrm{R}^{1} \mathrm{SeH}\right)$, generated in situ from diorganyl diselenides using glycerol as solvent and hypophosphorous 
acid as reducing agent (Scheme 3) [43]. Using this methodology, a large number of selenium-substituted pyridines were synthesized in high yields. In addition, after extraction of the products 2 with a hexane/ethyl acetate mixture $(95: 5 \mathrm{v} / \mathrm{v})$, the glycerol $/ \mathrm{H}_{3} \mathrm{PO}_{2}$ system could be easy recovered and reused for five times without loss of efficiency.

$$
\begin{aligned}
& \mathrm{R}^{1} \mathrm{Se}-\mathrm{SeR}^{1}+\mathrm{H}_{3} \mathrm{PO}_{2} \frac{\text { 1) glycerol } / 90^{\circ} \mathrm{C} / 30 \mathrm{~min}}{\text { 2) }} \\
& \text { (1) (70-97\% yield) } \\
& \text { (2 equiv.) } \\
& \mathrm{R}^{1}=\mathrm{Ph}, 4-\mathrm{C}_{6} \mathrm{H}_{4} \mathrm{Me}, 2-\mathrm{C}_{6} \mathrm{H}_{4} \mathrm{Me}, 1,3,5-\mathrm{C}_{6} \mathrm{H}_{2} \mathrm{Me}_{3}, 4-\mathrm{C}_{6} \mathrm{H}_{4} \mathrm{OMe}, 4-\mathrm{C}_{6} \mathrm{H}_{4} \mathrm{Cl}, 4-\mathrm{C}_{6} \mathrm{H}_{4} \mathrm{Br} \text {, } \\
& 4-\mathrm{C}_{6} \mathrm{H}_{4} \mathrm{~F}, 3-\mathrm{C}_{6} \mathrm{H}_{4} \mathrm{CF}_{3}, \mathrm{Bn}, n-\mathrm{Bu} ; \mathrm{R}^{2}=\mathrm{H} \\
& \mathrm{R}^{1}=\mathrm{Ph} ; \mathrm{R}^{2}=\mathrm{Cl}, \mathrm{NH}_{2}
\end{aligned}
$$

Scheme 3. Protocol for the preparation of 2-organoselanyl pyridines using glycerol as solvent.

On a different plane, glycerol has been recognized in recent years as an effective promoting medium for the electrophilic activation of carbonyl compounds, its use as solvent enabling the development of transformations that conventionally require of Brønsted- or Lewis-acid catalysts [30-35]. The ability of glycerol to establish a strong hydrogen bond network with the carbonyl group is behind this activating effect. In this context, glycerol has been recently employed as a convenient reaction medium for the aza-Michael addition of aromatic amines to enones under catalyst-free conditions (Scheme 4) [44]. Remarkably, traditional organic solvents such as dichloromethane, toluene, acetonitrile or methanol were ineffective for this reaction, and only modest conversions were achieved in water or ionic liquids ([Bmim] $]\left[\mathrm{BF}_{4}\right]$ or $[\mathrm{Bmim}]\left[\mathrm{PF}_{6}\right] ;$ Bmim $=$ 1-butyl-3-methylimidazolium). Using the addition of aniline to chalcone as model reaction, the recyclability of the glycerol solvent was also demonstrated (five times without loss of reactivity after extraction of the reaction product with ethyl acetate). 


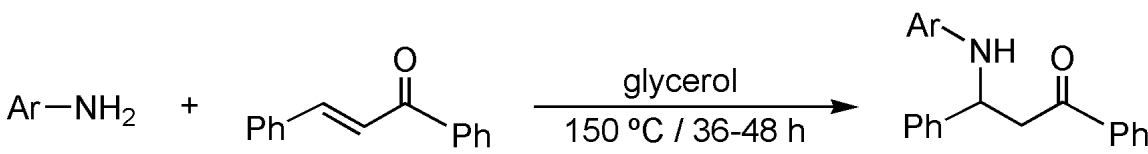

$$
\begin{aligned}
& \text { (92-97\% yield) } \\
& \mathrm{Ar}=\mathrm{Ph}, 4-\mathrm{C}_{6} \mathrm{H}_{4} \mathrm{Me}, 4-\mathrm{C}_{6} \mathrm{H}_{4} \mathrm{OMe}
\end{aligned}
$$$$
\mathrm{Ar}-\mathrm{NH}_{2}+\underset{\begin{array}{c}
100^{\circ} \mathrm{C} / 24-48 \mathrm{~h} \\
(68-92 \% \text { yield })
\end{array}}{\stackrel{\text { glycerol }}{\longrightarrow}}
$$$$
\mathrm{n}=1,2 ; \mathrm{Ar}=\mathrm{Ph}, 2-\mathrm{C}_{6} \mathrm{H}_{4} \mathrm{Me}, 4-\mathrm{C}_{6} \mathrm{H}_{4} \mathrm{Me}, 2-\mathrm{C}_{6} \mathrm{H}_{4} \mathrm{Br}, 4-\mathrm{C}_{6} \mathrm{H}_{4} \mathrm{Cl} \text { (6 examples) }
$$

Scheme 4. Aza-Michael addition reactions between aromatic amines and enones in glycerol.

Sadek and co-workers successfully employed glycerol as solvent and promoter for the one-pot synthesis of a variety of 2-arylbenzothiazoles 3 , by condensation of 2 aminothiophenols with aromatic aldehydes, at room temperature, under catalyst-free conditions (Scheme 5) [45]. Worthy of note, the starting materials were recovered almost unchanged when the same reactions were studied in other solvents, such as acetone, chloroform or water. In a closely related study, faster transformations (4-8 min; 78-96\% yield) were observed performing the reactions in glycerol under MW irradiation conditions (180 W; $100 \stackrel{\circ}{\circ})[46]$.

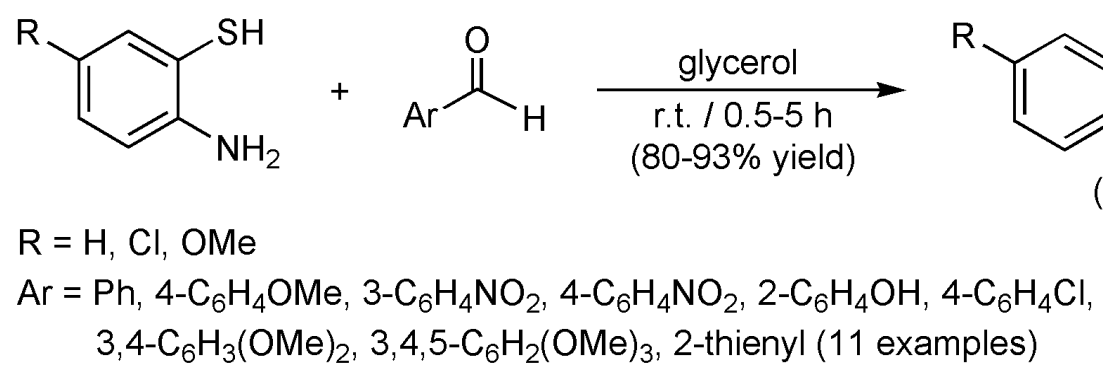

Scheme 5. One-pot synthesis of 2-arylbenzothiazoles in glycerol.

Taking advantage of the activating effect exerted by glycerol on carbonyl compounds, Perin and Jacob employed this solvent for the one-pot hetero-Diels-Alder (HDA) cycloaddition of the naturally occurring aldehyde $(R)$-citronellal with different arylamines 
(Scheme 6) [47]. These catalyst-free reactions proceeded cleanly at $90{ }^{\circ} \mathrm{C}$ to afford the desired octahydroacridines 4 , as separable mixtures of diastereoisomers, in good to excellent yields. Remarkably, after removing the insoluble products 4 from the reaction media through a simple decantation, glycerol could be reutilized without loss of effectiveness (up to four consecutive runs).

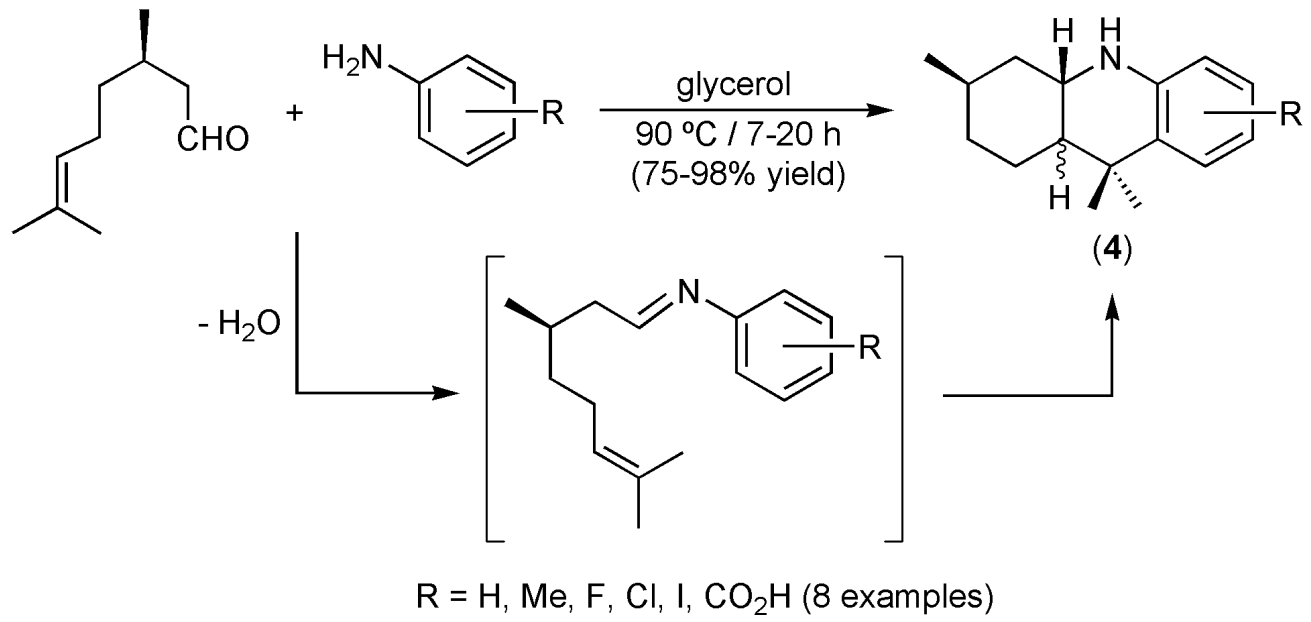

Scheme 6. Synthesis of octahydroacridines in glycerol under catalyst-free conditions.

Similarly, catalyst-free condensation of o-phenylenediamine with several aldehydes and enolizable ketones was found to proceed cleanly in glycerol to furnish the corresponding benzimidazoles 5 and benzodiazepines 6, respectively (Scheme 7) [48]. As in the preceding case, after extraction of the final reaction products with a hexane/ethyl acetate mixture (95:5 $v / v)$, glycerol could be reused without purification for further reactions (up to five runs). Related couplings of o-phenylenediamine with different cinnamic acids in glycerol also afforded the expected 2-styrylbenzimidazoles 7 in high yields (Scheme 7) [49]. In addition, protocols for the synthesis of quinaxoline and benzoxazole derivatives by condensation of $o$ aminophenol and o-phenylenediamine with aldehydes or 1,2-diketones, respectively, in glycerol have also been developed by Telvekar and co-workers [50]. 


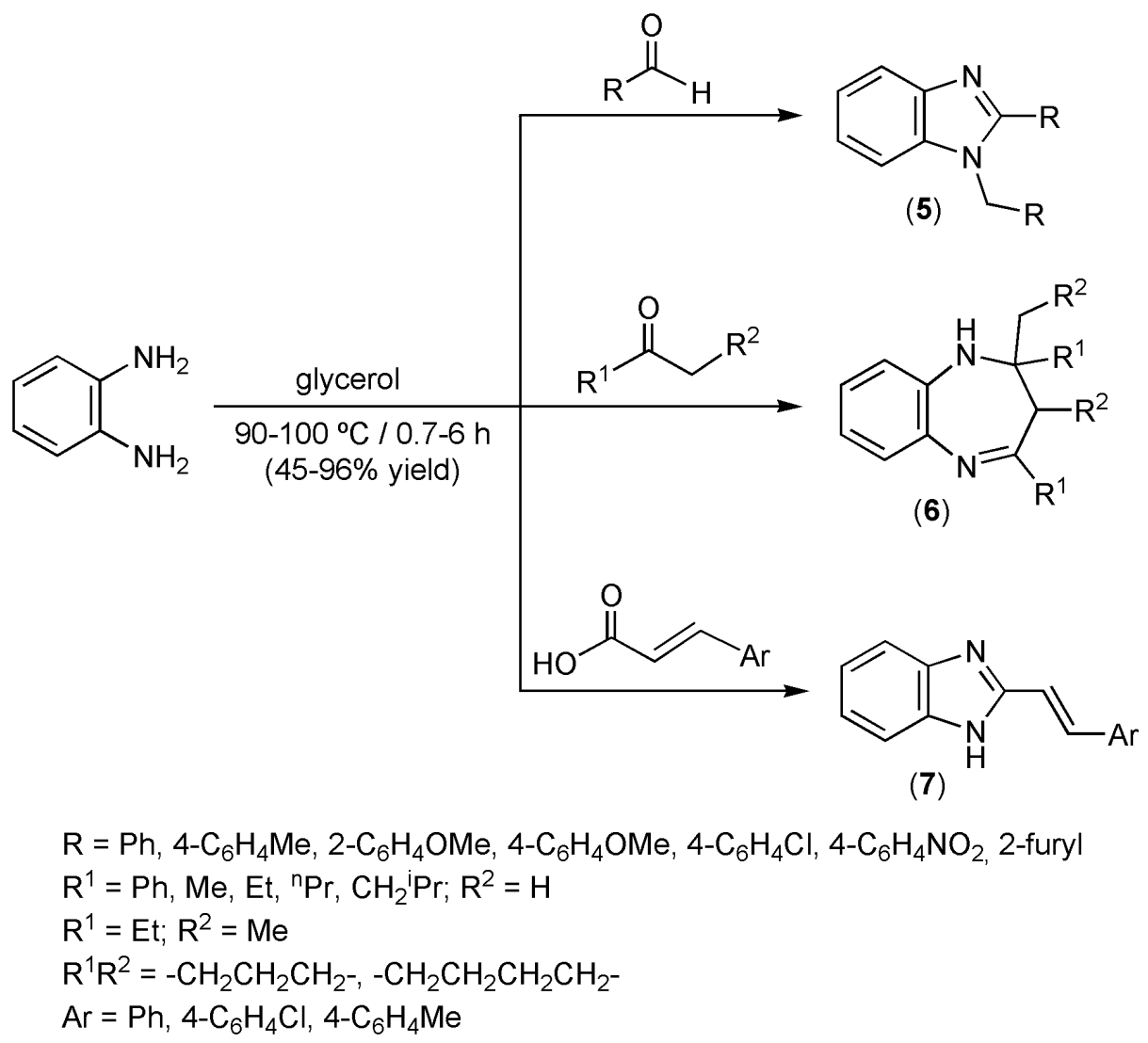

Scheme 7. Catalyst-free synthesis of benzimidazoles and benzodiazepines using glycerol.

The uncatalyzed cyclocondensation of quinolino-chalcones 8 with hydrazine hydrate in glycerol at $90{ }^{\circ} \mathrm{C}$ was recently described by Jagrut and co-workers, the reactions affording pyrazolines 9 in high yields (Scheme 8) [51]. Similarly, broad series of push-pull styryl dyes (some representative examples are shown in Figure 1) have been prepared in glycerol by Deligoergiev and co-workers through uncatalyzed condensations between aromatic aldehydes and $\mathrm{N}$-alkylated salts of 2-methylazoles, 2-methylthiazoles, 2-methyloxazoles or 4-methylpyridine derivatives [52].

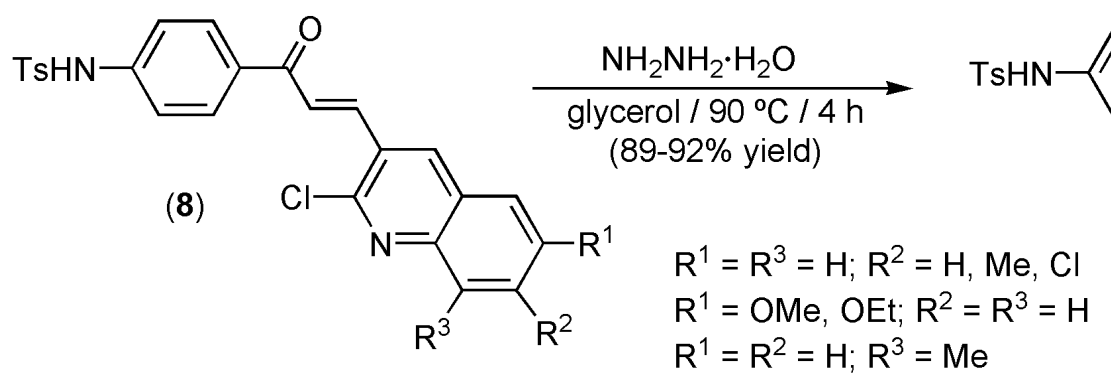

(9)<smiles>[R]c1cc2cc(C3CC(c4ccccc4)=NN3)c(Cl)nc2c([R])c1[R]</smiles>

Scheme 8. Catalyst-free synthesis of pyrazolines in glycerol. 

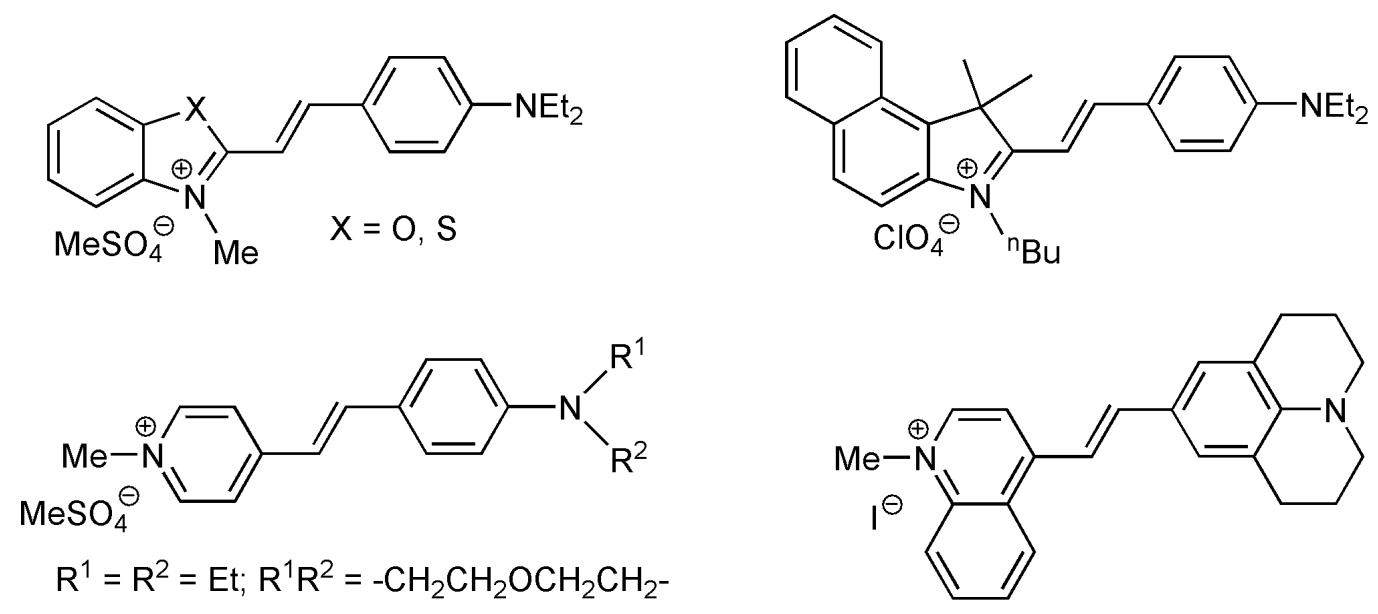

Figure 1. Structure of some push-pull dyes generated in glycerol through condensation reactions.

Condensation of $\alpha$-bromoketones with thiourea/thioamide compounds also occurred rapidly in glycerol, under mild reaction conditions (r.t.) and without using any catalyst, to generate the corresponding substituted thiazole derivatives 10 with high yields and selectivity (Scheme 9) [53]. Once again, after extraction of the final reaction products with ethyl acetate, glycerol could be used for further reactions without any problem.

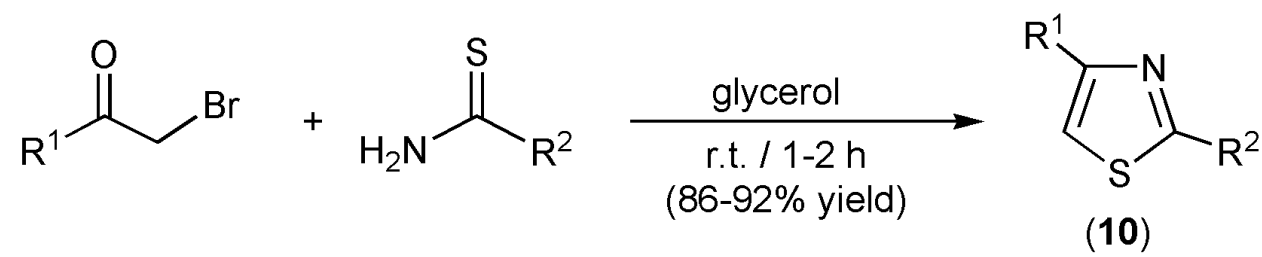

$\mathrm{R}^{1}=\mathrm{Ph}, 4-\mathrm{C}_{6} \mathrm{H}_{4} \mathrm{Br}$, 2-naphthyl; $\mathrm{R}^{2}=\mathrm{NH}_{2}, \mathrm{NHMe}, \mathrm{Me}, \mathrm{Ph}$ (12 examples)<smiles>[R]c1ccc(C(=O)CBr)cc1</smiles>

$\mathrm{R}=\mathrm{H}, \mathrm{F}, \mathrm{Cl}, \mathrm{Me}, \mathrm{OMe}, \mathrm{OH}, \mathrm{Ph}, \mathrm{CN}$ (10 examples)

Scheme 9. Catalyst-free synthesis of thiazole derivatives in glycerol. 
In an independent report, an effective synthesis of related 2-cyanomethyl-4phenylthiazoles $\mathbf{1 1}$ from different substituted 2-bromoacetophenones and 2cyanothioacetamide was also described (Scheme 9) [54]. Reactions, which were in this case performed under MW conditions, delivered the desired products with high purity and yields after very short irradiation periods $(3-4.5 \mathrm{~min})$. It is worthy of note that the same transformations were studied in polyethylene glycol 400 (PEG-400) and remarkably lower yields were reached.

Glycerol and PEG-400 were also employed as green reaction media for the preparation of different heterocyclic 2-thiones 12 (2-thiobenzothiazoles, 2-thiobenzoxazoles, 2-thiobenzimidazoles and 1,3-oxazolopyridine-2-thiols), an important class of compounds with numerous applications and a wide range of biological activities [55]. They were generated by coupling of 2-aminophenols, 2-aminothiophenols, 1,2-phenylenediamines or 2amino-3-hydroxypyridines with potassium O-ethyldithiocarbonate under MW irradiation (Scheme 10). The experiments did not highlighted which solvent, glycerol or PEG-400, was better in terms of reaction yields or rates, since good to excellent yields were attained in both solvents after short irradiation periods. However, according to its lower price and environmental impact, glycerol would be more advantageous.

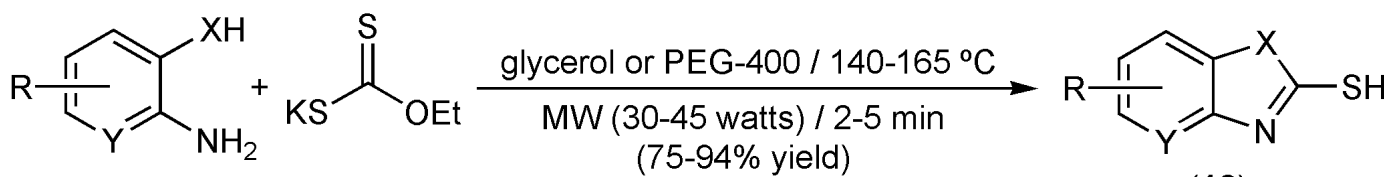

$\mathrm{X}=\mathrm{O}, \mathrm{S}, \mathrm{NH} ; \mathrm{Y}=\mathrm{CH}, \mathrm{N}$

$\mathrm{R}=\mathrm{H}, \mathrm{Cl}, \mathrm{Me}, \mathrm{NO}_{2}, \mathrm{COPh}$ (11 examples)

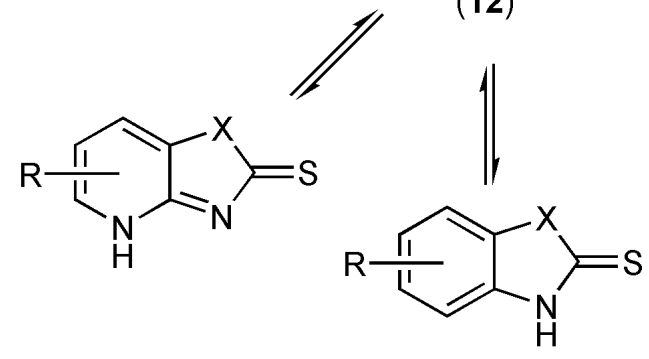

Scheme 10. Synthesis of heterocyclic 2-thiones in glycerol or PEG-400.

A cost-effective and environmentally benign method of synthesis of $\mathrm{N}$-aryl phthalimide derivatives $\mathbf{1 3}$ from phthalic anhydride and primary aromatic amines in glycerol 
has been presented by Shankarling and co-workers (Scheme 11) [56]. Glycerol played the dual role of catalyst and solvent in this condensation process which conventionally requires acidic catalysts to proceed. The reactions, which were performed at $80{ }^{\circ} \mathrm{C}$ and could be scaled up to $50 \mathrm{~g}$ of phthalic anhydride, delivered the desired products in moderate to high yields and short times, with good recyclability of the recovered glycerol (up to five consecutive runs). Similar results in terms of yields and recyclability were obtained using biodegradable deep eutectic solvents (mixtures of choline chloride/urea and choline chloride/malonic acid) as the reaction media.

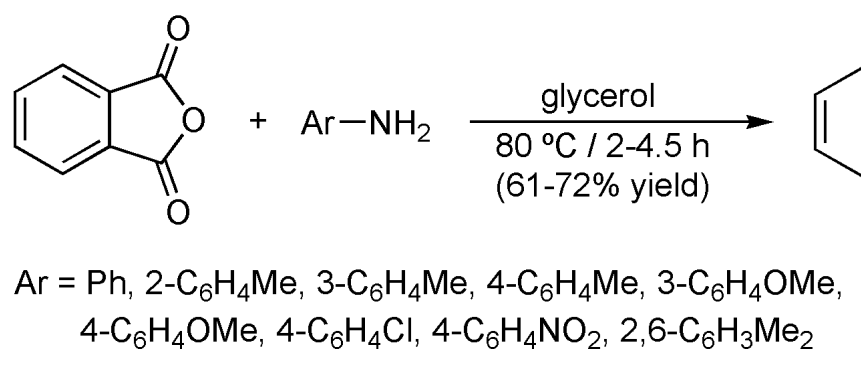<smiles>O=C1c2ccccc2C(=O)N1Br</smiles>

Scheme 11. Synthesis of $N$-arylphthalimides in glycerol.

The high-yield synthesis of several 5-substituted $1 H$-tetrazoles 14 , via uncatalyzed [3 + 2] cycloaddition reactions of organonitriles with $\mathrm{NaN}_{3}$ in glycerol, has also been reported (Scheme 12) [57]. The exceptional $\mathrm{H}$-bonding properties of glycerol, able to activate the $\mathrm{C} \equiv \mathrm{N}$ unit towards the nucleophilic attack of $\mathrm{N}_{3}{ }^{-}$, were again evoked to rationalize the higher reactivity observed in this medium as compared to more classical organic solvents and water.<smiles>[R]c1ccc([Al]C#N)cc1</smiles>

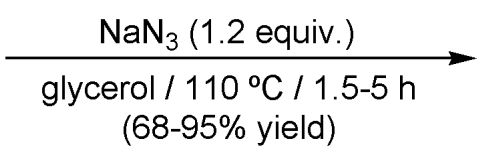
$(68-95 \%$ yield)<smiles>[R]c1cccc(Cc2nnn[nH]2)c1</smiles>

(14)

$\mathrm{n}=0,1 ; \mathrm{R}=\mathrm{H}, \mathrm{Me}, \mathrm{OMe}, \mathrm{NO}_{2}, \mathrm{~F}, \mathrm{Cl}, \mathrm{Br}$ (14 examples)

Scheme 12. Catalyst-free [3 +2$]$ cycloadditions of nitriles with sodium azide in glycerol. 
On the other hand, the combination of multicomponent reactions (MCRs), in which at least three different substrates join through covalent bonds in a single operation, and green solvents has emerged in recent years as an important research area within organic synthesis [58]. Glycerol has proved to be a convenient platform to perform this type of transformations [30-35]. In this context, Kumar has recently reported that three-component coupling of 4-hydroxycoumarin, aldehydes and $\mathrm{N}, \mathrm{N}$-dialkylanilines rapidly occurs in this medium, under very mild reaction conditions, to afford the C3-benzylated 4-hydroxycoumarin derivatives 16 (Scheme 13) [59]. The process, which does not require the assistance of any acidic or metal catalyst, proceeds via $\mathrm{C}-\mathrm{H}$ hydroarylation of in situ generated ortho-quinone methide intermediates 15 by the anilines. Related transformations involving 4hydroxypyrone, cyclohexane-1,3-dione and dimedone, instead of 4-hydroxycoumarin, allowed the high-yield $(\geq 70 \%$ ) preparation of compounds 17-18 [59]. All these unusual three-component coupling reactions were found to occur also in water and other alcohols, such as methanol or ethanol, but with remarkably lower efficiency.
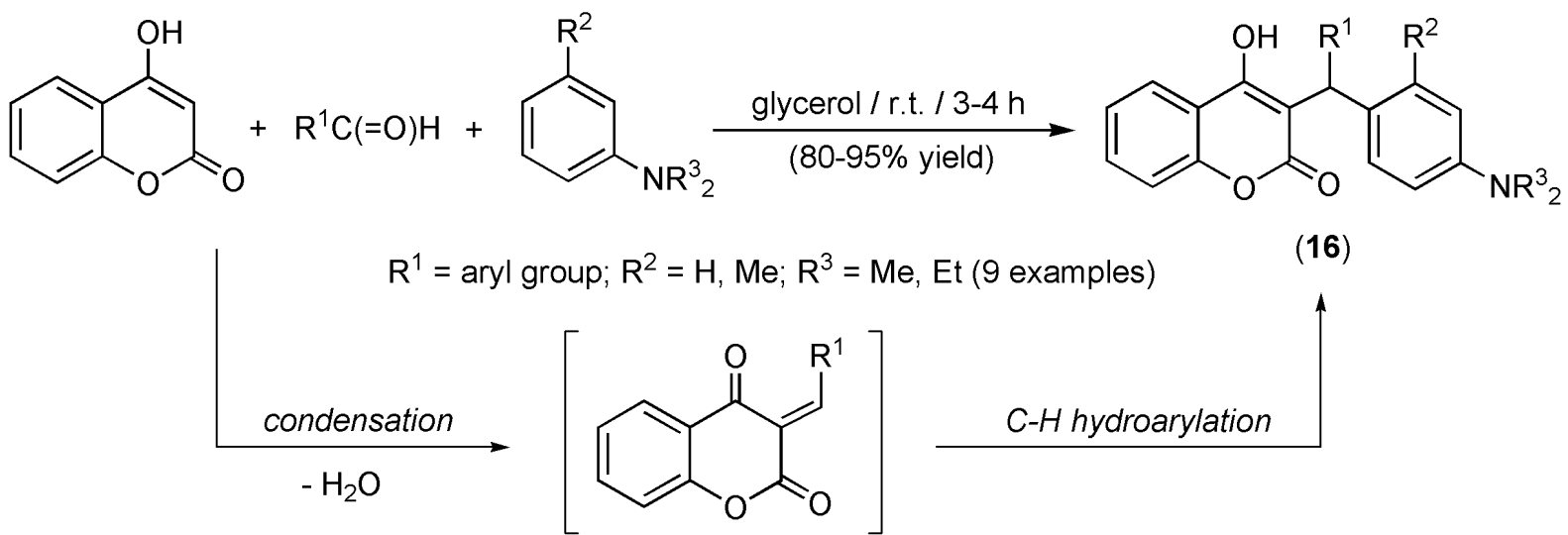

(15)<smiles>[R]c1cc(N(C)C)ccc1C([R])c1c(O)cc(C)oc1=O</smiles>

(17)<smiles>[R]C(C1=C(O)CC([R1])([R])CC1=O)c1ccc([NH2+][O-])cc1C</smiles>

(18)

$\mathrm{R}^{1}=\mathrm{H}$, aryl or alkyl group; $\mathrm{R}^{2}=\mathrm{H}$ or Me (9 examples) $\quad \mathrm{R}^{1}=\mathrm{H}, \mathrm{Me} ; \mathrm{R}^{2}=\mathrm{H}$ or aryl group (3 examples)

Scheme 13. Three-component coupling of 4-hydroxycoumarin, aldehydes and $\mathrm{N}, \mathrm{N}$-dialkylanilines in glycerol. 
Three-component synthesis of a variety of $4 H$-pyrans 19 , by condensation of aromatic aldehydes with carbonyl compounds possessing a reactive $\alpha$-methylene group and alkylmalonates or malononitrile, was also found to proceed cleanly in glycerol under catalystfree conditions (Scheme 14) [60]. Reactions proceeded in short times giving the products in excellent yields, and the medium could be recycled and reused several times. As in the preceding case, water and related polar solvents (ethanol, PEG-400, ethylene glycol) were also able to promote the reaction, but with remarkably lower efficiency.
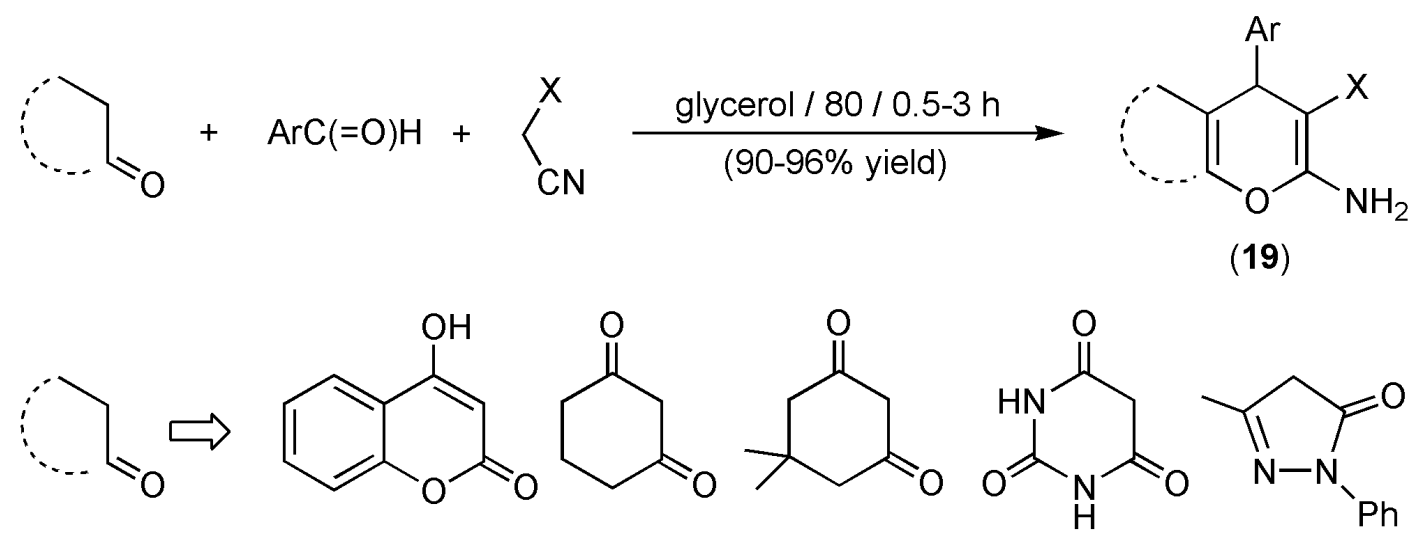

$\mathrm{Ar}=$ aryl or heteroaryl group; $\mathrm{X}=\mathrm{CO}_{2} \mathrm{Me}, \mathrm{CO}_{2} \mathrm{Et}, \mathrm{CN}$ (49 examples)

Scheme 14. Catalyst-free three-component synthesis of $4 H$-pyrans in glycerol.

Somwanshi and co-workers employed glycerol as a promoting and recyclable solvent in the one-pot imino-Diels-Alder reaction of aldehydes, amines and 2,3-dihydrofuran [61]. As shown in Scheme 15, the corresponding furanoquinolines 20 were generated in good yields with a complete endo diastereoselectivity. Following a similar approach, several pyranoquinolines could also be synthesized using 3,4-dihydro- $2 H$-pyran as the dienophile [61].

An effective catalyst-free method of synthesis of 2,4,5-triaryl-imidazol derivatives 21 in glycerol, via multicomponent coupling of benzil, aromatic aldehydes and ammonium acetate, has been recently described by Nemati and co-workers (Scheme 16) [62]. Using this new protocol, the yields of $\mathbf{2 1}$ were better than those obtained in conventional organic 
media (MeOH, EtOH, acetonitrile or PEG-400), and comparable to those previously reported in the literature under acid or metal catalysis.

$$
\begin{aligned}
& \mathrm{R}=\mathrm{H} ; \mathrm{Ar}=\mathrm{Ph}, 4-\mathrm{C}_{6} \mathrm{H}_{4} \mathrm{~F}, 4-\mathrm{C}_{6} \mathrm{H}_{4} \mathrm{OMe} \\
& \mathrm{R}=4-\mathrm{OMe}, 3,5-(\mathrm{OMe})_{2} ; \mathrm{Ar}=4-\mathrm{C}_{6} \mathrm{H}_{4} \mathrm{~F} \\
& \mathrm{R}=4-\mathrm{Me} ; \mathrm{Ar}=4-\mathrm{C}_{6} \mathrm{H}_{4} \mathrm{Cl}
\end{aligned}
$$

Scheme 15. Synthesis of furanoquinolines in glycerol under catalyst-free conditions.

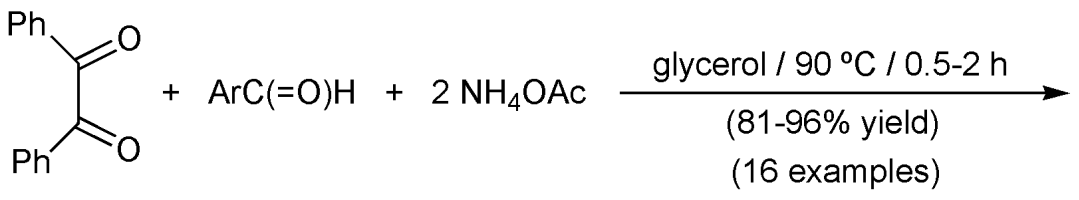

Scheme 16. Synthesis of 2,4,5-triaryl-imidazoles in glycerol under catalyst-free conditions.

Using polystyrene-poly(ethylene glycol) resin-supported sulfonic acid (PS-PEG$\mathrm{OSO}_{3} \mathrm{H}$ ) as catalyst, Wang and co-workers also reported a series of MCRs for the synthesis of 3,4-dihydropyrimidones 22, amidoalkyl-naphthols 23 and dibenzoxanthenes 24 in glycerol (Scheme 17) [63]. Excellent products yields and good recyclability of the solvent/catalyst system (up to five cycles after extraction of the reaction products with ethyl acetate) were in all cases achieved.

On another matter, due to its easy access and low cost, polyaniline (PANI) is one of the most studied conducting polymers (Figure 2). This polymer is usually synthesized by chemical or electrochemical oxidation of aniline in aqueous media or, alternatively, in the solid state. Recently, oxidative polymerization of aniline and aniline hydrochloride by means of ammonium peroxydisulfate was for the first time performed in a non-aqueous environment consisting of ethylene glycol or glycerol [64]. Interestingly, the oxidation of aniline hydrochloride led to PANI with a standard emeraldine structure in both reaction media, and with conductivity properties similar to those of PANI prepared in water. In contrast, the 
oxidation of aniline produced oligomeric materials showing a remarkably lower conductivity. To the best of our knowledge, this work represents the first application of glycerol as solvent for polymers synthesis.<smiles>O=CC([18F])Br</smiles><smiles></smiles>

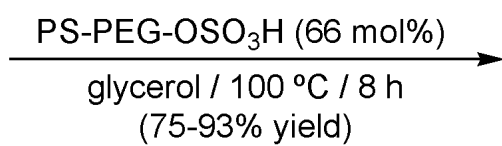<smiles>[X]C1NC(C)=C(C(=O)OCC)C(Br)N1</smiles>

(22)

$\mathrm{X}=\mathrm{O}, \mathrm{S} ; \mathrm{Ar}=\mathrm{Ph}, 4-\mathrm{C}_{6} \mathrm{H}_{4} \mathrm{OMe}, 4-\mathrm{C}_{6} \mathrm{H}_{4} \mathrm{Me}, 2-\mathrm{C}_{6} \mathrm{H}_{4} \mathrm{Cl}, 4-\mathrm{C}_{6} \mathrm{H}_{4} \mathrm{Cl}, 3-\mathrm{C}_{6} \mathrm{H}_{4} \mathrm{NO}_{2}, 4-\mathrm{C}_{6} \mathrm{H}_{4} \mathrm{NO}_{2}$ (11 examples)

OHCHO $+\mathrm{RC}(=\mathrm{O}) \mathrm{NH}_{2}$

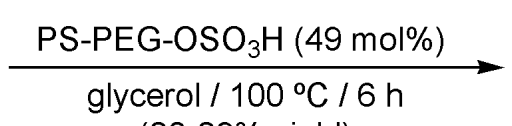
(80-89\% yield)<smiles>[R]C(=O)NC([Al])c1c(O)ccc2ccccc12</smiles>

(23)

$\mathrm{R}=\mathrm{Me}, \mathrm{Ph} ; \mathrm{Ar}=\mathrm{Ph}, 4-\mathrm{C}_{6} \mathrm{H}_{4} \mathrm{OMe}, 4-\mathrm{C}_{6} \mathrm{H}_{4} \mathrm{Me}, 4-\mathrm{C}_{6} \mathrm{H}_{4} \mathrm{Cl}, 3-\mathrm{C}_{6} \mathrm{H}_{4} \mathrm{NO}_{2}, 4-\mathrm{C}_{6} \mathrm{H}_{4} \mathrm{NO}_{2}$ (7 examples)

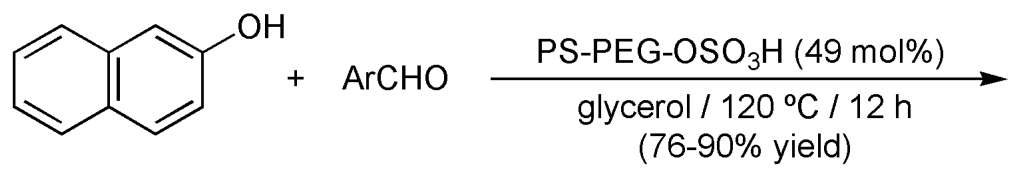<smiles>[Al]C1c2c(ccc3ccccc23)Oc2ccc3ccccc3c21</smiles>

(24)

$\mathrm{Ar}=\mathrm{Ph}, 4-\mathrm{C}_{6} \mathrm{H}_{4} \mathrm{OMe}, 4-\mathrm{C}_{6} \mathrm{H}_{4} \mathrm{Me}, 2-\mathrm{C}_{6} \mathrm{H}_{4} \mathrm{Cl}, 4-\mathrm{C}_{6} \mathrm{H}_{4} \mathrm{Cl}, 3-\mathrm{C}_{6} \mathrm{H}_{4} \mathrm{NO}_{2}, 4-\mathrm{C}_{6} \mathrm{H}_{4} \mathrm{NO}_{2}$

Scheme 17. PS-PEG-OSO ${ }_{3} \mathrm{H}$-catalyzed MCRs in glycerol.<smiles>[Y]OS(=O)(=O)Nc1ccc(Nc2ccc(NC(C)CCCCCCC)cc2)cc1</smiles>

Figure 2. Structure of the conducting polyaniline polymer. 


\section{Metal-catalyzed transformations}

The utility of glycerol as solvent in homogeneous catalysis was demonstrated for the first time by Wolfson and co-workers in 2007, performing a series of Heck- and SuzukiMiyaura-type C-C couplings in this medium under conventional oil bath (OB) heating and MW irradiation $[36,65]$. Using $\mathrm{PdCl}_{2}, \mathrm{Pd}(\mathrm{OAc})_{2}$ and $\mathrm{Pd} / \mathrm{C}$ as the palladium sources and the coupling of 4-iodoanisole with $\mathrm{PhB}(\mathrm{OH})_{2}$ as model reaction, the same group has recently found that the effectiveness of the Suzuki-Miyaura C-C coupling can be strongly improved under sonochemical (US) conditions. The excellent acoustic cavitation provided by glycerol, and a more effective dispersion of the reactants in the medium, was evoked to explain the shorter reaction times and higher yields observed [66]. In a related study, Mata, Colacino and co-workers also showed the beneficial effect exerted by the ultrasounds in this C-C coupling process catalyzed by the palladium $\mathrm{N}$-heterocyclic carbene $(\mathrm{NHC})$ catalysts $\mathbf{2 5 - 2 8}$ [67]. As shown in the example given in Scheme 18, the reactions performed under pulsedultrasound activation (P-US) were significantly more effective than those carried out using classical oil bath heating. In addition, the generality of the process was in this case clearly demonstrated for a variety of aryl halides (bromides and iodides) and aryl-boron derivatives (boronic acids and boronate salts), as well as the recyclability of the solvent/catalyst system (up to three consecutive runs with complex 27).

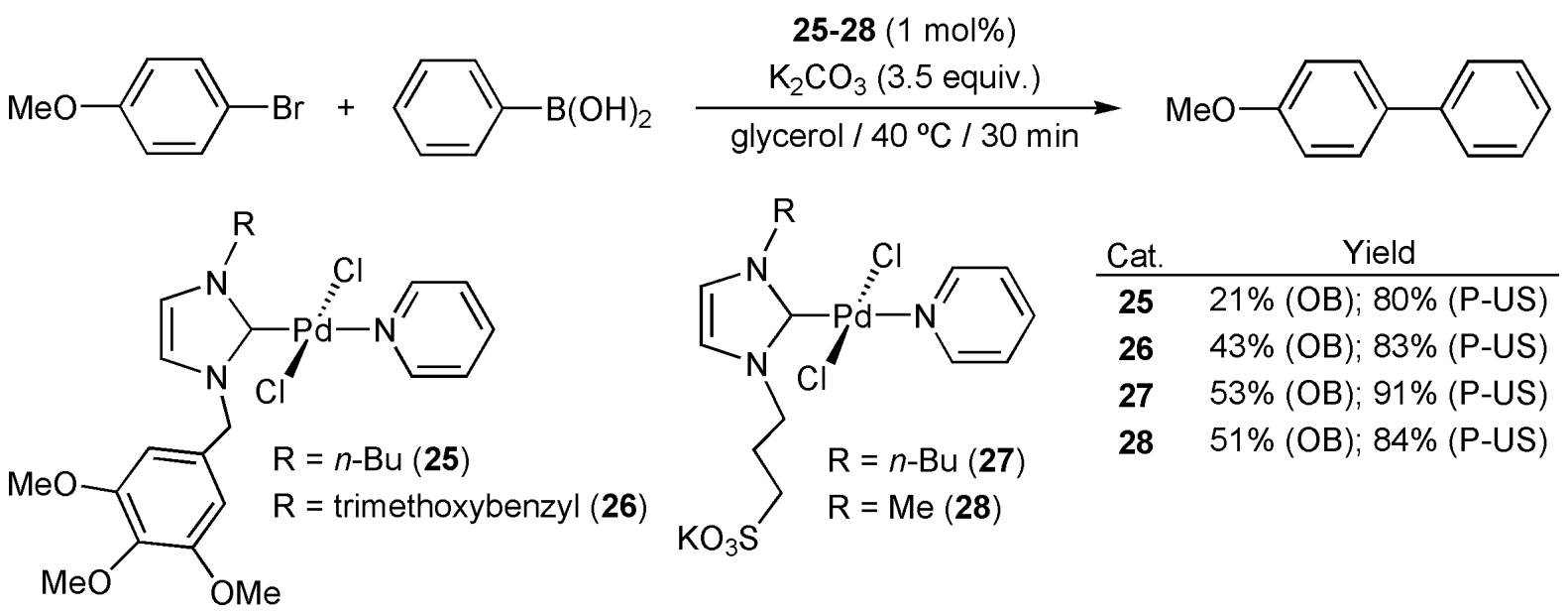

Scheme 18. Effect of ultrasounds in Suzuki-Miyaura C-C couplings performed in glycerol. 
Employing conventional oil-bath heating, the coupling of more challenging aryl chlorides could be successfully accomplished at $80 \stackrel{\circ}{ } \mathrm{C}$ with the dinuclear $\mathrm{Pd}(\mathrm{II})$ complex 29 in a glycerol/water solvent mixture (Scheme 19) [68]. It is worthy of note that the use of glycerol or water alone led to the desired biphenyl products in remarkably lower yields. In addition to all these Suzuki-Miyaura C-C couplings, the effective Sonogashira alkynylation of 4-iodoanisole with phenylacetylene in glycerol, using a recyclable $\mathrm{Pd} / \mathrm{Cu}$ loaded polymeric cyclodextrin catalyst, has also been recently described [69].

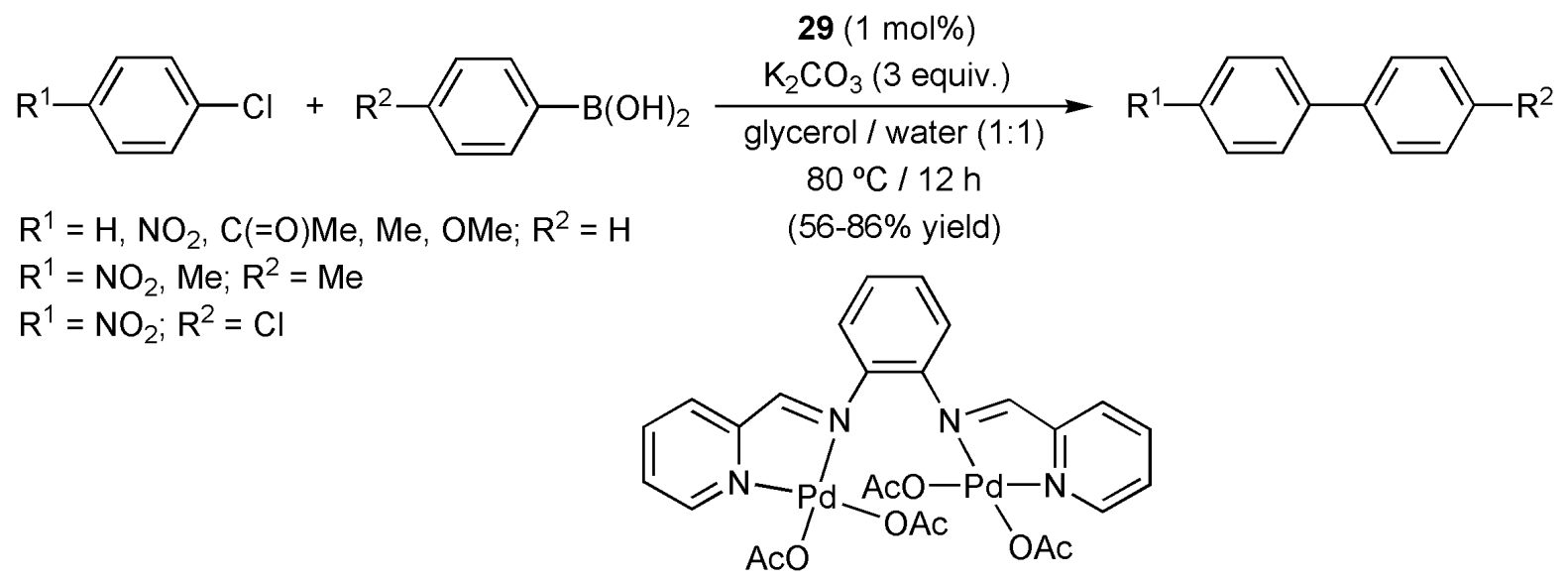

(29)

Scheme 19. Cross-coupling of aryl chlorides with arylboronic acids in a glycerol/water mixture.

An efficient and greener protocol for the copper-catalyzed $\mathrm{N}$-arylation of amines, a process usually performed in toxic DMF and DMSO, has been recently disclosed by using glycerol as solvent (Scheme 20) [70]. Once the reactions finished, the products were easily isolated in excellent yields, by extraction with diethyl ether, and the catalytic glycerol/copper system reused for six runs without loss of efficiency. Remarkably, aryl-aryl homocoupling side-products were not formed during these reactions. 


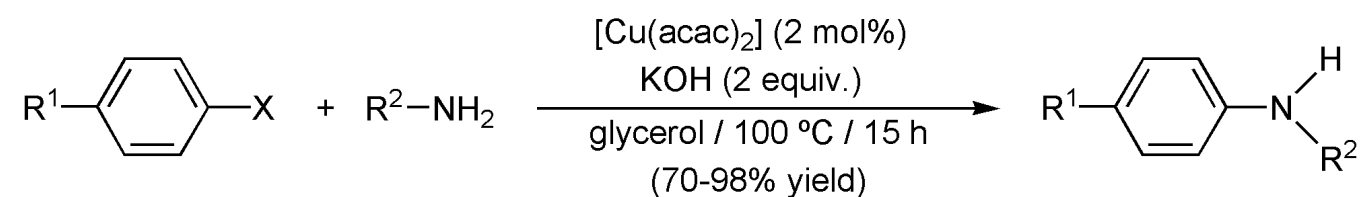

$\mathrm{X}=\mathrm{Br}, \mathrm{I} ; \mathrm{R}^{1}=\mathrm{H}, \mathrm{Cl}, \mathrm{Me}, \mathrm{OMe} ; \mathrm{R}^{2}=\mathrm{Ph}, \mathrm{Bn}, \mathrm{Cy}$ (14 examples)

Scheme 20. Copper-catalyzed $\mathrm{N}$-arylation of amines in glycerol.

Following with their studies on the use of glycerol for Cul-catalyzed cross-coupling reactions of diaryl diselenides [71], Jacob, Alves and co-workers have now described that the glycerol-Cul mixture is able to promote the cross-coupling of diaryl diselenides with arylboronic acids in the presence of DMSO as additive (Scheme 21) [72]. The process was applicable to substrates bearing both electron-withdrawing and electron-donating substituents, leading to the corresponding diaryl selenides in high yields, and the solvent and catalyst could be effectively reused (up to five times) after extraction of the reaction products with hexane/diethyl acetate $(95: 5 \mathrm{v} / \mathrm{v})$. The process was found to be also operative starting from diphenyl ditelluride and diphenyl disulfide, albeit remarkably lower yields were attained with the latter.

$$
\begin{aligned}
& \mathrm{Ar}^{1}-\mathrm{Se}-\mathrm{Se}-\mathrm{Ar}^{1}+2 \mathrm{Ar}^{2}-\mathrm{B}(\mathrm{OH})_{2} \underset{\text { glycerol } / 110^{\circ} \mathrm{C} / 30 \mathrm{~h} / \text { air }}{\stackrel{\mathrm{Cul}(5 \mathrm{~mol} \%) / \mathrm{DMSO}(2 \text { equiv. }}{\longrightarrow}} 2 \mathrm{Ar}^{1}-\mathrm{Se}-\mathrm{Ar}^{2} \\
& \text { (73-90\% yield) } \\
& \mathrm{Ar}^{1}=\mathrm{Ph}, 4-\mathrm{C}_{6} \mathrm{H}_{4} \mathrm{OMe}, 4-\mathrm{C}_{6} \mathrm{H}_{4} \mathrm{Me}, 2-\mathrm{C}_{6} \mathrm{H}_{4} \mathrm{Me}, 4-\mathrm{C}_{6} \mathrm{H}_{4} \mathrm{Cl}, 3-\mathrm{C}_{6} \mathrm{H}_{4} \mathrm{CF}_{3}, 2,4,6-\mathrm{C}_{6} \mathrm{H}_{2} \mathrm{Me}_{3} \\
& \mathrm{Ar}^{2}=2-\mathrm{C}_{6} \mathrm{H}_{4} \mathrm{OMe}, 4-\mathrm{C}_{6} \mathrm{H}_{4} \mathrm{OMe}, 2-\mathrm{C}_{6} \mathrm{H}_{4} \mathrm{Me}, 4-\mathrm{C}_{6} \mathrm{H}_{4} \mathrm{Me}, 2-\mathrm{C}_{6} \mathrm{H}_{4} \mathrm{Cl}, 4-\mathrm{C}_{6} \mathrm{H}_{4} \mathrm{Cl}, 2-\mathrm{C}_{6} \mathrm{H}_{4} \mathrm{Br} \text {, } \\
& \text { 4- } \mathrm{C}_{6} \mathrm{H}_{4} \mathrm{Br}, 3-\mathrm{C}_{6} \mathrm{H}_{4} \mathrm{CF}_{3} \text {, 2-naphthyl (17 examples) }
\end{aligned}
$$

Scheme 21. Cu-catalyzed cross-coupling reactions of diaryl diselenides with arylboronic acids in glycerol.

Since the pioneering works by Crotti's [73] and Wolfson's groups [74] in 2009, glycerol has emerged as an appealing alternative to replace propan-2-ol as solvent and hydrogen donor in metal-catalyzed transfer hydrogenation (TH) reactions of unsaturated organic compounds [75]. In this context, using as model the reduction of benzaldehyde to benzyl alcohol catalyzed by $\left[\left\{\mathrm{RuCl}(\mu-\mathrm{Cl})\left(\eta^{6}-p \text {-cymene }\right)\right\}_{2}\right]$, Wolfson and co-workers demonstrated recently that, as observed in the Suzuki-Miyaura C-C couplings described 
above and also in Barbier-type reactions [66], the use of ultrasounds dramatically accelerates the $\mathrm{TH}$ reactions [66]. Thus, using a combination of potassium and sodium hydroxide (1-2 mol\%) as the base, benzyl alcohol was quantitatively generated in $3 \mathrm{~h}$ under sonochemical conditions, at $60 \stackrel{\circ}{\mathrm{C}}$ and with only $1 \mathrm{~mol} \%$ of $\left[\left\{\mathrm{RuCl}(\mu-\mathrm{Cl})\left(\eta^{6}-p \text {-cymene }\right)\right\}_{2}\right]$ (Scheme 22) [66], while $24 \mathrm{~h}$ and a ruthenium loading of 25 mol\% were previously required to attain a similar conversion employing a classical oil bath heating $\left(70^{\circ} \mathrm{C}\right)$ [74].

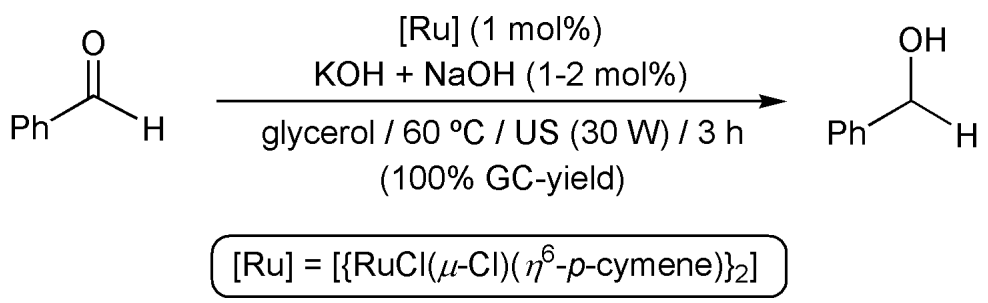

Scheme 22. Ru-catalyzed TH of benzaldehyde in glycerol under US conditions.

Mata and co-workers studied different $\operatorname{Ir}(\mathrm{III})$ and $\operatorname{Ir}(\mathrm{I})$ complexes, bearing $\mathrm{NHC}(\mathrm{N}$ heterocyclic carbene) ligands (30-33 in Figure $\mathbf{3})$, as potential catalysts for the $\mathrm{TH}$ of carbonyl compounds in glycerol $[76,77]$. Combined with $\mathrm{KOH}$ (1 equiv.), and performing the catalytic reactions at $120^{\circ} \mathrm{C}$ (oil bath heating), all the complexes $\mathbf{3 0 - 3 3}$ (2.5 mol\% of Ir) were able to reduce acetophenone and benzaldehyde to the corresponding alcohols after $7 \mathrm{~h}[76]$. The reduction of benzaldehyde proceeded, in general, in higher yields (66-99\%) than that of acetophenone (25-80\%). Complex 31 was particularly active with both substrates and also proved effective in the reduction of benzophenone ( $91 \%$ yield after $20 \mathrm{~h}$ ) [76]. The catalytic behavior of complexes $\mathbf{3 0 - 3 3}$ in the transfer hydrogenation of acetophenone and benzaldehyde was also explored employing MW and US activation [77]. As previously observed by Wolfson and co-workers, a drastic reduction of the reaction times was observed using ultrasounds, the use of this technique allowing also the reduction of the iridium loadings. As an example, using only 1 mol\% of $\mathbf{3 2 a}$, benzaldehyde could be converted into benzyl alcohol in $73 \%$ yield after 5 min. Optimal dispersion of the reactants in the reaction medium explained again the improvements observed under sonochemical conditions. 

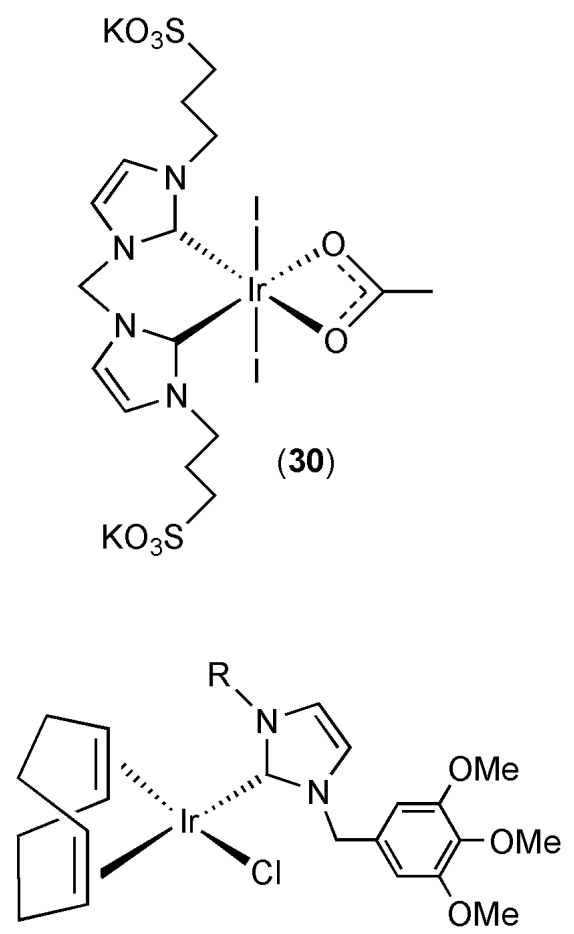

$\mathrm{R}=n-\mathrm{Bu}(32 \mathrm{a})$

$\mathrm{R}=$ trimethoxybenzyl (32b)
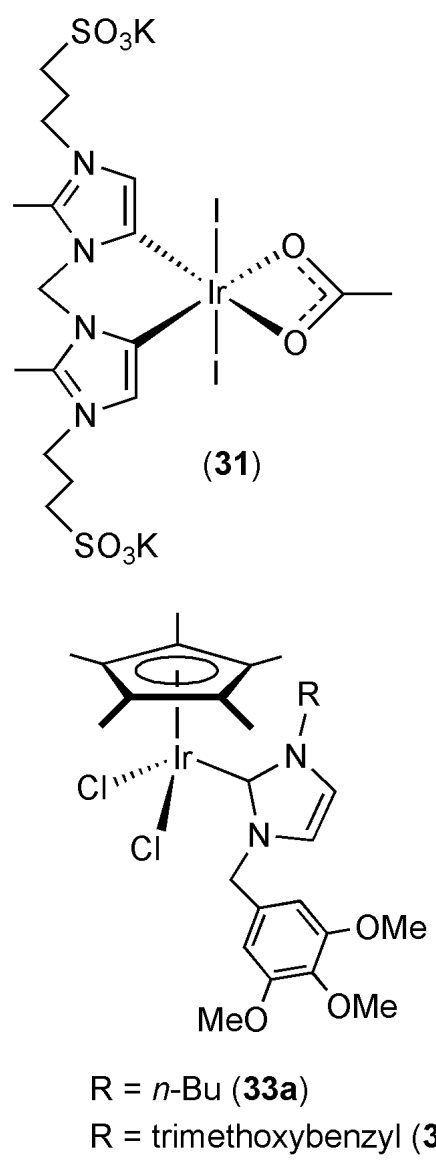

$(33 b)$

Figure 3. The iridium-NHC catalysts 30-33.

The iridium(III)-NHC complexes $\mathbf{3 0}$ and $\mathbf{3 1}$ were also employed as catalysts for the transfer hydrogenation of $\mathrm{C}=\mathrm{C}$ bonds in glycerol, but only modest results were achieved [75]. However, the remarkably high chemoselectivity observed in the $\mathrm{TH}$ of $\alpha, \beta$-unsaturated ketones merits to be highlighted (Scheme 23). Thus, while selective reduction of the olefinic bonds of benzylideneacetone and dibenzylideneacetone took place with both catalysts, leading to the corresponding carbonylic products without competitive formation of fully hydrogenated compounds, starting from cinnamaldehyde reduction of both $\mathrm{C}=\mathrm{C}$ and $\mathrm{C}=\mathrm{O}$ functionalities to form the saturated alcohol 3-phenylpropan-1-ol was observed. These results support again the greater tendency of the $\operatorname{Ir}(\mathrm{III})$ catalysts $\mathbf{3 0 - 3 1}$ to promote the transfer hydrogenation of aldehydes over ketones. The ability of complexes $30-31$ to promote the $\mathrm{TH}$ of phenylacetylene by glycerol was also evaluated with a very modest success (only $12-30 \%$ yield of styrene was reached after $14 \mathrm{~h}$ of heating at $120{ }^{\circ} \mathrm{C}$ with 2.5 
mol\% of 30-31 and 1 equiv. of $\mathrm{KOH}$ ). We must also note that, in all these transfer hydrogenation reactions, formation of dihydroxyacetone by dehydrogenation of glycerol was proposed, but without any experimental evidence.

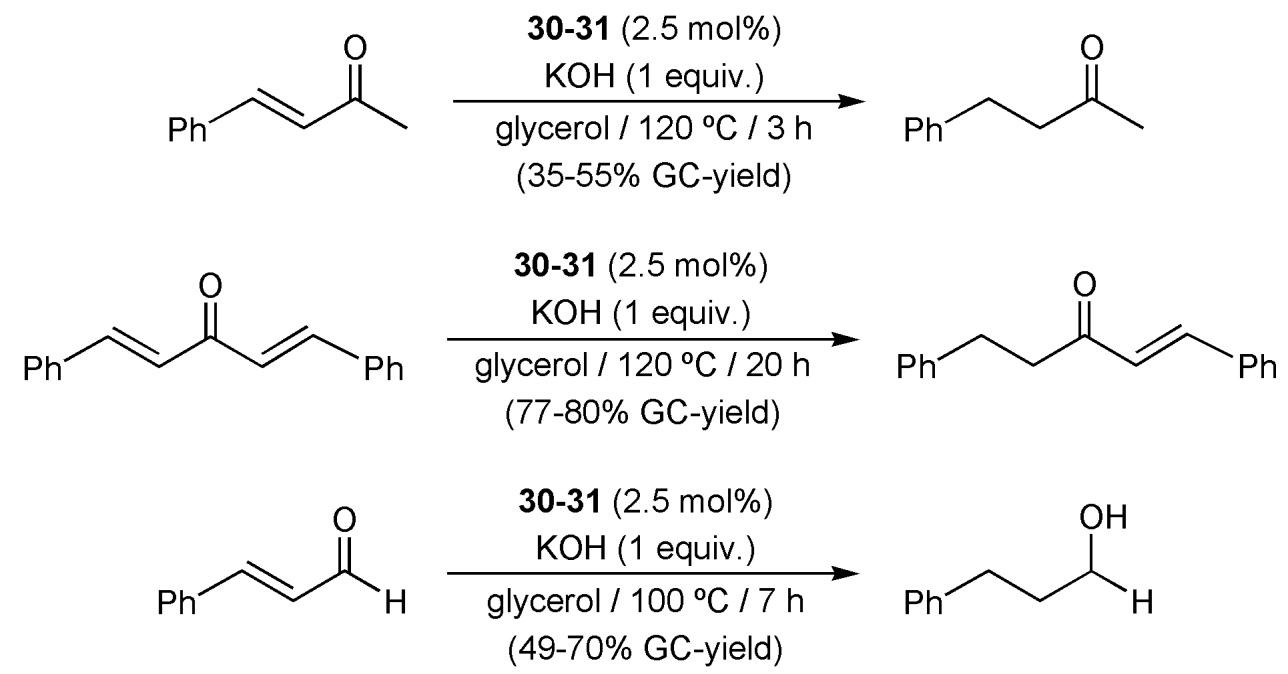

Scheme 23. TH of enones and enals in glycerol using Ir-NHC catalysts.

Selective reduction of allylic alcohols in glycerol has been described employing different arene-ruthenium(II) complexes $\left[\mathrm{RuCl}_{2}\left(\eta^{6}\right.\right.$-arene)L] (arene $=\mathrm{C}_{6} \mathrm{H}_{6}, p$-cymene, mesitylene, $\mathrm{C}_{6} \mathrm{Me}_{6} ; \mathrm{L}=$ water-soluble phosphine) as promoters [78]. Complex $\left[\mathrm{RuCl}_{2}\left(\eta^{6}-\right.\right.$ $\left.\mathrm{C}_{6} \mathrm{H}_{6}\right)($ DAPTA)] (34; DAPTA = 3,7-diacetyl-1,3,7-triaza-5-phosphabicyclo[3.3.1]nonane), in combination with $\mathrm{KOH}$, was particularly effective leading to the selective formation of the desired saturated alcohols in high yields (Scheme 24). The use of technical (87\% purity) instead of pharmaceutical (99.5\% purity) grade glycerol was tolerated in this catalytic transformation, which had been previously studied in water and propan-2-ol [79-81]. Interestingly, in marked contrast with these previous studies, the use of glycerol allowed the recovery and recycling (up to 4 times) of the catalytically active species. It is also worthy of note that this reduction process does not involve a direct transfer hydrogenation of the $\mathrm{C}=\mathrm{C}$ bond of the allylic alcohol by glycerol. Instead two independent reactions take place: $(i)$ the initial redox-isomerization of the substrate, and (ii) the subsequent transfer hydrogenation of the $\mathrm{C}=\mathrm{O}$ unit in the resulting aldehyde intermediate. The initial step, i.e. the redox- 
isomerization of an allylic alcohol into the corresponding saturated carbonyl compound, has been independently studied in glycerol by García-Álvarez and co-workers [82]. Using the ruthenium(IV) complex $\left[\mathrm{RuCl}_{2}\left(\eta^{3}: \eta^{3}-\mathrm{C}_{10} \mathrm{H}_{16}\right)\right.$ (benzimidazole)] $\left(\mathrm{C}_{10} \mathrm{H}_{16}=\right.$ 2,7-dimethylocta-2,6diene-1,8-diyl) as catalyst $(0.2 \mathrm{~mol} \%)$ and 1 -octen-3-ol as model substrate, complete conversion of the alcohol into octan-3-one was achieved after $45 \mathrm{~min}$ of heating at $75^{\circ} \mathrm{C}$. However, for this particular transformation, the use of a deep eutectic mixture of choline chloride/glycerol (2:1 ratio) resulted more effective (quantitative yield after $10 \mathrm{~min}$ ).
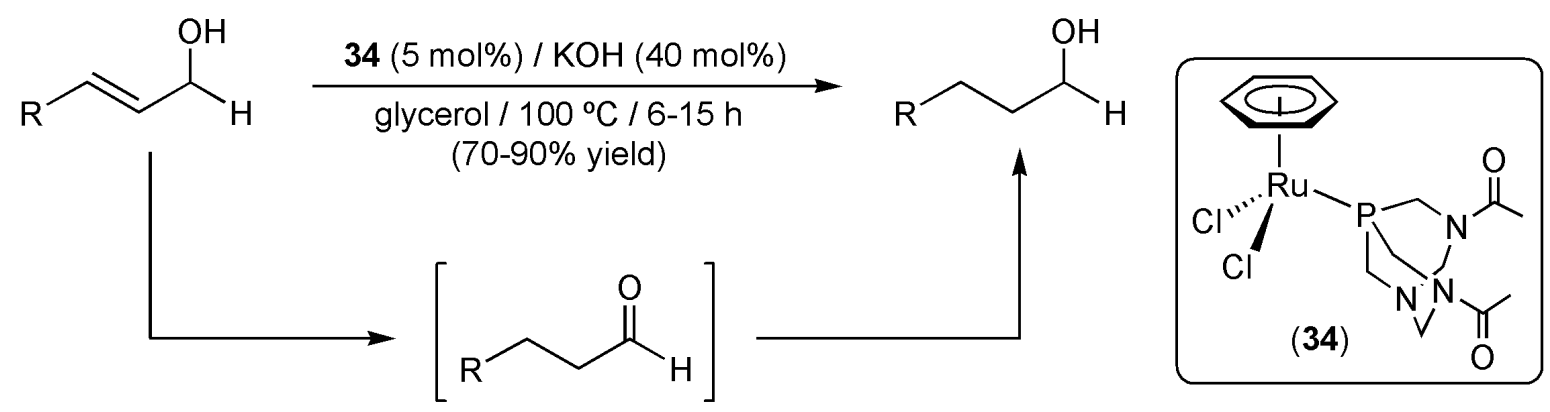

$\mathrm{R}=\mathrm{Ph}, 2-\mathrm{C}_{6} \mathrm{H}_{4} \mathrm{OMe}, 4-\mathrm{C}_{6} \mathrm{H}_{4} \mathrm{OMe}, 4-\mathrm{C}_{6} \mathrm{H}_{4} \mathrm{~F}, n-\mathrm{C}_{5} \mathrm{H}_{11}, n-\mathrm{C}_{6} \mathrm{H}_{13}$

Scheme 24. Reduction of allylic alcohols in glycerol through a tandem isomerization/TH process.

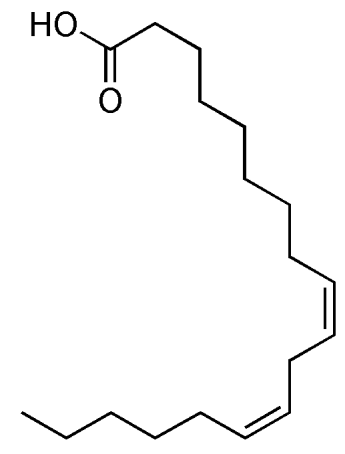

(35)

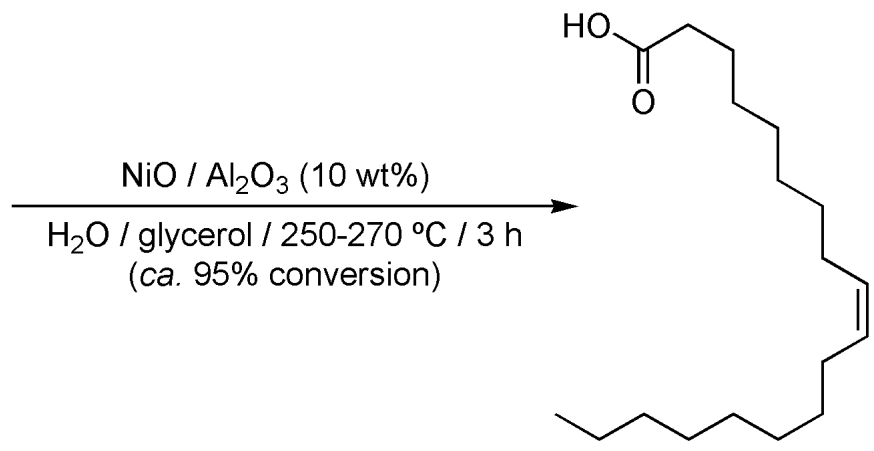

(36)

Scheme 25. Catalytic transfer hydrogenation of linoleic acid.

The transformation of linoleic 35 to oleic acid 36 by direct reduction of one of its $\mathrm{C}=\mathrm{C}$ bonds was observed as a side reaction during the hydrolysis of soybean oil and tallow employing heterogeneous nickel-based catalysts [83]. As shown in Scheme 25, $\mathrm{NiO} / \mathrm{Al}_{2} \mathrm{O}_{3}$ was particularly effective in this reduction process in which the glycerol generated during the hydrolysis of the triglycerides acts as the hydrogen source. 
Conversion of nitroarenes to the corresponding amines is a synthetically useful transformation in organic chemistry. Different reagents and methodologies to promote this reduction process are presently available as, for example, the use of stoichiometric Raney nickel under transfer hydrogenation conditions. In this regard, Wolfson and co-workers have recently demonstrated that glycerol can be employed as solvent and hydrogen donor for the Raney Ni-mediated reduction of nitroarenes [84]. Thus, performing the reactions in the presence of sodium hydroxide (2.5 equiv.), different substituted nitroarenes were successfully converted into the corresponding anilines (44-81\% yield) after $24 \mathrm{~h}$ of heating at $100 \stackrel{\circ}{ } \mathrm{C}$, the reactions being particularly effective when electron-withdrawing substituents are present in the substrates. Further studies in the field have shown that ferrite-nickel magnetic nanoparticles $\left(\mathrm{Fe}_{3} \mathrm{O}_{4}-\mathrm{Ni} \mathrm{MNPs}\right)$, combined with $\mathrm{KOH}$, are much more effective for the reduction of nitroarenes in glycerol than Raney nickel, allowing to employ milder reaction conditions and reducing drastically the reaction times (Scheme 26) [85]. In addition, in marked contrast with Raney $\mathrm{Ni}$, in this case no marked differences in activity were observed when using nitroarenes substituted with electron-donating groups. It is also worthy of note the high chemoselectivity shown by this magnetic nanocatalyst, since it is able to reduce selectively the nitro functionality when carbonyl groups are also present in the molecule. To explain this unusual chemoselectivity, the authors propose that interaction of nitro group with the surface of the nanoparticles is stronger compared to that of the carbonyl one. Moreover, after magnetic separation with the help of an external magnet, the $\mathrm{Fe}_{3} \mathrm{O}_{4}$ - $\mathrm{Ni}$ nanoparticles could be recycled, showing almost the same activity and selectivity during eight consecutive uses. The $\mathrm{Fe}_{3} \mathrm{O}_{4}$-Ni MNPs proved also effective in the reduction of carbonyl compounds under similar reaction conditions [85]. 


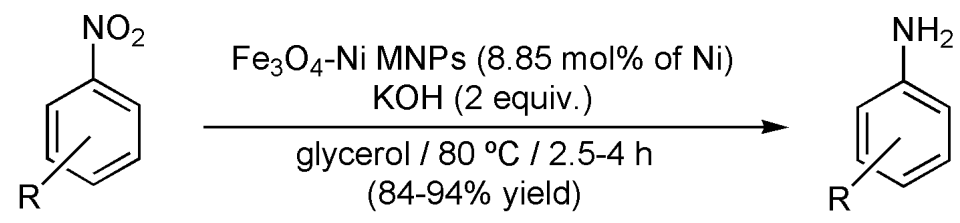
$\mathrm{R}=\mathrm{H}, 2-\mathrm{Me}, 3-\mathrm{Me}, 2-\mathrm{OMe}, 3-\mathrm{OMe}, 4-\mathrm{OMe}, 2-\mathrm{Cl}, 3-\mathrm{Cl}$, $3-\mathrm{Br}, 4-\mathrm{Br}, 4-\mathrm{F}, 2,5-\mathrm{Cl}_{2}, 4-\mathrm{OH}, 2-\mathrm{NH}_{2}, 3-\mathrm{NO}_{2}, 4-\mathrm{CN}$, $4-\mathrm{CO}_{2} \mathrm{Et}, 4-\mathrm{C}(=\mathrm{O}) \mathrm{Me}$

Scheme 26. TH of nitroaromatic compounds in glycerol using $\mathrm{Fe}_{3} \mathrm{O}_{4}-\mathrm{Ni}$ nanoparticles as catalyst.

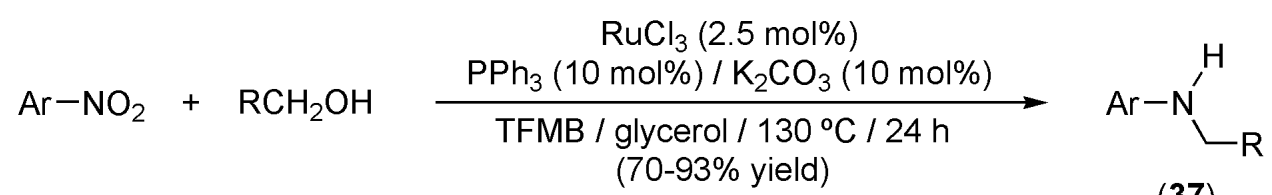

$\mathrm{Ar}=\mathrm{Ph}, 4-\mathrm{C}_{6} \mathrm{H}_{4} \mathrm{Me}, 4-\mathrm{C}_{6} \mathrm{H}_{4} \mathrm{OMe}, 4-\mathrm{C}_{6} \mathrm{H}_{4} \mathrm{Cl}, 4-\mathrm{C}_{6} \mathrm{H}_{4} \mathrm{Br}$, 2-naphthyl; $\mathrm{R}=\mathrm{Ph}$

$\mathrm{Ar}=4-\mathrm{C}_{6} \mathrm{H}_{4} \mathrm{Me} ; \mathrm{R}=\mathrm{CH}_{2} \mathrm{Ph}, 3-\mathrm{C}_{6} \mathrm{H}_{4} \mathrm{Me}, 4-\mathrm{C}_{6} \mathrm{H}_{4} \mathrm{SMe}, \mathrm{Cy}, \mathrm{CH}_{2}{ }^{i} \mathrm{Pr},{ }^{\mathrm{n} P r}, n-\mathrm{C}_{5} \mathrm{H}_{11}, n-\mathrm{C}_{7} \mathrm{H}_{15}, n-\mathrm{C}_{8} \mathrm{H}_{17}$

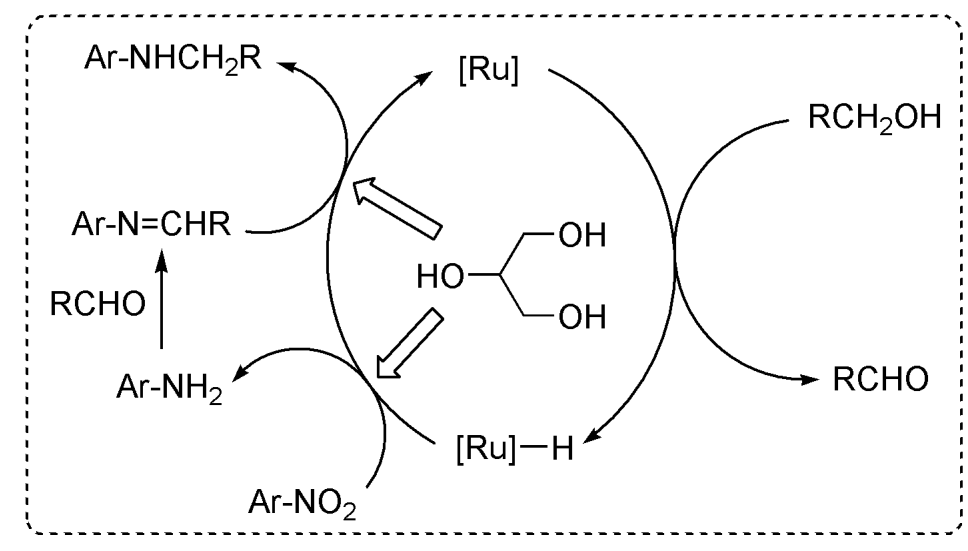

Scheme 27. Catalytic synthesis of $N$-substituted amines from different nitrobenzenes and alcohols.

With the help of glycerol, nitrobenzenes could be successfully employed as starting materials for the reductive amination of primary alcohols (Scheme 27) [86]. The process, catalyzed by the $\mathrm{RuCl}_{3} / \mathrm{PPh}_{3} / \mathrm{K}_{2} \mathrm{CO}_{3}$ combination in a mixture of glycerol and (trifluoromethyl)benzene (TFMB), afforded the desired $N$-substituted amines 37 in $70-93 \%$ yield after $24 \mathrm{~h}$ of heating at $130^{\circ} \mathrm{C}$. In the proposed catalytic cycle, glycerol acted as the reducing agent for the nitro group as well as for the imine intermediates generated during the catalytic events. Remarkably, when the same reactions were performed with two equivalents of the alcohol at $150{ }^{\circ} \mathrm{C}, \mathrm{N}, \mathrm{N}$-disubstituted amines $\left(\mathrm{Ar}-\mathrm{N}\left(\mathrm{CH}_{2} \mathrm{R}\right)_{2}\right)$ could also be synthesized in high yields. 
Reduction of carboxylic acids to primary alcohols by transfer hydrogenation in glycerol has been recently patented employing a catalytic system composed of $\mathrm{CoCl}_{2} \cdot 6 \mathrm{H}_{2} \mathrm{O}$ and $\mathrm{KOH}$ [87]. As shown in Scheme 28, performing the catalytic reactions at $140-150{ }^{\circ} \mathrm{C}$ for $1 \mathrm{~h}$, the desired alcohols were selectively formed in very high yields. This new route is an alternative to the most common methods based on the use of $\mathrm{H}_{2}$ and $\mathrm{NaBH}_{4}$ as reducing agents.

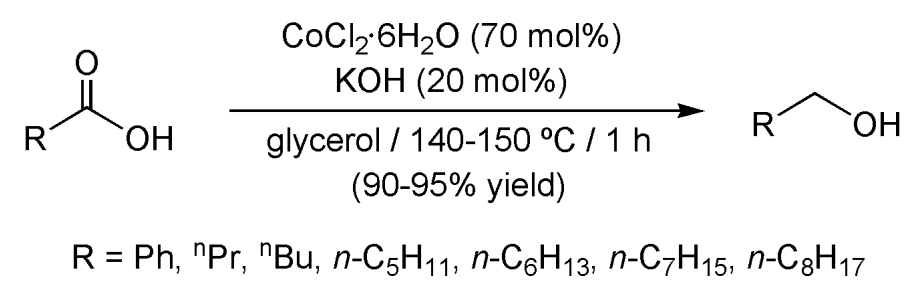

Scheme 28. Catalytic conversion of carboxylic acids to primary alcohols using glycerol as solvent and hydrogen donor.

In the presence of the ruthenium(II) complex $\left[\mathrm{RuCl}_{2}\left(\mathrm{PPh}_{3}\right)_{3}\right]$ and $\mathrm{KOH}$, aqueous glycerol acted also as a $\mathrm{H}$-donor to $\mathrm{CO}_{2}$ (Scheme 29) [88]. However, the effectiveness of the process was very low (TON of only a few units) in comparison with previous examples using propan-2-ol as the solvent and the hydrogen source [89]. However, it is important to stress that, in the reaction depicted in Scheme 29, two value-added products, i.e. formic acid $\left(\mathrm{HCO}_{2} \mathrm{H}\right)$ and glycolic acid $\left(\mathrm{HOCH}_{2} \mathrm{CO}_{2} \mathrm{H}\right)$, are formed from two waste products. The search for more active catalysts for this transformation represents therefore an attractive challenge. Note that the glycolic acid is generated from glycerol by decarbonylation of the initially formed dihydroxyacetone (the expected dehydrogenation product of glycerol) by action of the ruthenium catalyst.

$$
\begin{aligned}
& \mathrm{CO}_{2}+\mathrm{HO} \underbrace{\mathrm{OH}}_{\text {glycerol } / \text { water } / \Delta} \underset{\mathrm{OH}}{\stackrel{\left[\mathrm{RuCl}_{2}\left(\mathrm{PPh}_{3}\right)_{3}\right] / \mathrm{KOH}}{\longrightarrow}} \mathrm{HCOOH}+\mathrm{HOH}^{\mathrm{O}}
\end{aligned}
$$

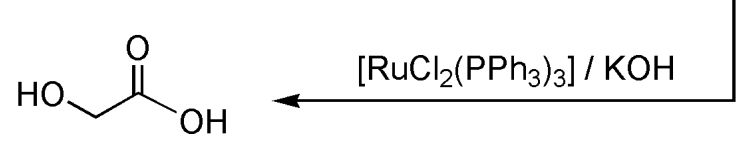

Scheme 29. Ru-catalyzed $\mathrm{TH}$ of $\mathrm{CO}_{2}$ by aqueous glycerol. 
Microwave-assisted lignin depolymerization promoted by the heterogeneous catalyst Al-SBA-15 has been recently studied employing, among others hydrogen-donating solvents, glycerol [90]. In the best of the cases, ca. $25 \mathrm{wt} \%$ of the initial lignin could be converted into monomeric phenolic species, a much higher percentage to that reached in propan-2-ol (ca. 2 wt\%), but poorer in comparison to that achieved in formic acid (ca. 30 wt\%), the more effective hydrogen-donating solvent found in this study. Direct transfer of $\mathrm{H}_{2}$ and $\mathrm{CO}$ from glycerol to styrene has also been described by Andersson and co-workers using a combined system composed of $\left[\{\operatorname{Ir}(\mu-\mathrm{Cl})(\operatorname{cod})\}_{2}\right] /(\mathrm{S})$-BINAP, able to promote the dehydrogenative decarbonylation of glycerol to $\mathrm{CO}$ and $\mathrm{H}_{2}$, and the hydroformylation catalyst $\left[\mathrm{RhHCO}\left(\mathrm{PPh}_{3}\right)_{3}\right]$. Thus, performing the reaction at $210 \stackrel{\circ}{\circ}$, a mixture of $2-$ and 3 phenylpropionaldehyde (1:1 ratio) could be generated in $98 \%$ yield after $66 \mathrm{~h}$ of heating [91].

In an elegant work, Sanz and co-workers have demonstrated that glycerol can be effectively used as solvent and reducing agent in the Mo-catalyzed deoxygenation of sulfoxides (Scheme 30) [92]. The use of this widely available feedstock, which allowed easy product separation (extraction with hot toluene) and catalyst recycling (up to 5 cycles), represents a greener alternative to the previously described deoxygenating agents for the reduction of sulfoxides, such as phosphorous(III) reagents or silanes. Notably, the process showed an exquisite chemoselectivity, tolerating the presence of additional reducible functionalities in the substrates (halogens, C-C multiple bonds, cyano, esters and nitro groups), and it was operative even in crude glycerin (the unrefined glycerol generated during biodiesel production) containing as less as $5-8 \%$ of glycerol, leading to similar reaction times and only slightly lower yields in comparison with the use of refined glycerol. The concomitant transformation of glycerol into $\mathrm{CO}_{2}$ and formic acid during the catalytic reactions could also be unambiguously established. 


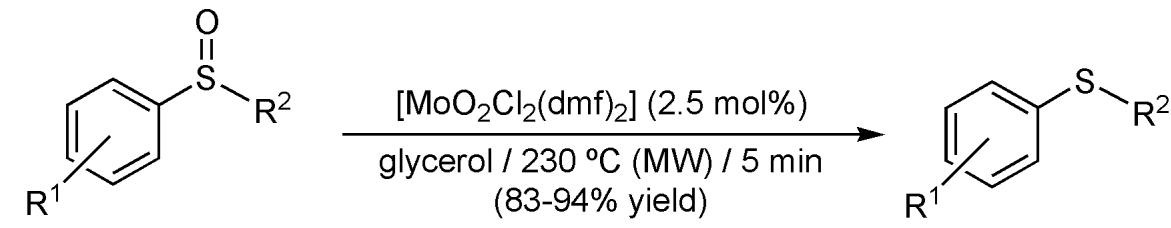

$\mathrm{R}^{1}=\mathrm{H}, 4-\mathrm{Me}, 4-\mathrm{Cl}, 4-\mathrm{Br}, 4-\mathrm{CN}, 4-\mathrm{NO}_{2}, 2-\mathrm{CO}_{2} \mathrm{Me}$

$\mathrm{R}^{2}=\mathrm{Ph}, 4-\mathrm{C}_{6} \mathrm{H}_{4} \mathrm{Me}, 4-\mathrm{C}_{6} \mathrm{H}_{4} \mathrm{Cl}, \mathrm{Me}, \mathrm{Bn}, \mathrm{c}-\mathrm{C}_{3} \mathrm{H}_{5},\left(\mathrm{CH}_{2}\right)_{3} \mathrm{CH}=\mathrm{CH}_{2}$ (12 examples)

Scheme 30. Reduction of sulfoxides in glycerol catalyzed by $\left[\mathrm{MoO}_{2} \mathrm{Cl}_{2}(\mathrm{dmf})_{2}\right]$

On another matter, an efficient synthetic protocol for the preparation of bis(indolyl)methanes 38 in glycerol, through the catalytic coupling of indole with various aldehydes by means of recyclable $\mathrm{FePO}_{4}$, has been described by Behbahani (Scheme 31) [93]. However, we must note that such a process is known to proceed in glycerol under catalyst-free conditions [94], or using $\mathrm{CeCl}_{3} \cdot 7 \mathrm{H}_{2} \mathrm{O}$ as Lewis-acid promoter [95], with similar efficiency.

2<smiles>[R]C=O</smiles>

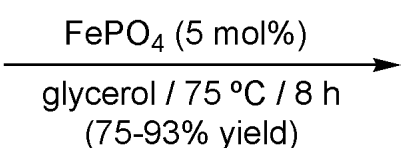

$(75-93 \%$ yield $)$<smiles>[R]C(c1c[nH]c2ccccc12)c1c[nH]c2ccccc12</smiles>

(38)

$\mathrm{R}=\mathrm{Ph}, 2-\mathrm{C}_{6} \mathrm{H}_{4} \mathrm{Cl}, 4-\mathrm{C}_{6} \mathrm{H}_{4} \mathrm{Cl}, 2-\mathrm{C}_{6} \mathrm{H}_{4} \mathrm{OMe}, 4-\mathrm{C}_{6} \mathrm{H}_{4} \mathrm{OMe}, 3,4-\mathrm{C}_{6} \mathrm{H}_{3}(\mathrm{OMe})_{2}$, 2- $\mathrm{C}_{6} \mathrm{H}_{4} \mathrm{OH}, 4-\mathrm{C}_{6} \mathrm{H}_{4} \mathrm{OH}, 4-\mathrm{C}_{6} \mathrm{H}_{4} \mathrm{Me}, 4-\mathrm{C}_{6} \mathrm{H}_{4} \mathrm{NO}_{2}, 4-\mathrm{C}_{6} \mathrm{H}_{4} \mathrm{NMe}_{2}$, 2-furyl, $(E)-\mathrm{CH}=\mathrm{CHPh},{ }^{n} \mathrm{Bu}, n-\mathrm{C}_{6} \mathrm{H}_{13}$

Scheme 31. Access to bis(indolyl)methanes catalyzed by $\mathrm{FePO}_{4}$ in glycerol.

Concerning the glycerol $/ \mathrm{CeCl}_{3} \cdot 7 \mathrm{H}_{2} \mathrm{O}$ combination, Narsaiah and co-workers employed this reaction medium for the synthesis of a number of quinoxalines by coupling of diketo carbonyls with 1,2-diamines (representative examples are shown in Scheme 32) [96]. The method was very efficient and applicable to aromatic, heteroaromatic and alicyclic 1,2diamine derivatives. In addition, after extraction of the reaction product with ethyl acetate, the catalytic glycerol/ $/ \mathrm{CeCl}_{3} \cdot 7 \mathrm{H}_{2} \mathrm{O}$ system could be successfully recycled (up to five consecutive runs). The same group also employed glycerol and $\mathrm{CeCl}_{3} \cdot 7 \mathrm{H}_{2} \mathrm{O}$ for the ringopening of oxiranes with amines and thioamides, generating the corresponding $\beta$-amino 
alcohols in high yields under remarkably mild reaction conditions (some examples are given in Scheme 32) [97]. As in the previous case, the catalytic system could be easily recycled.
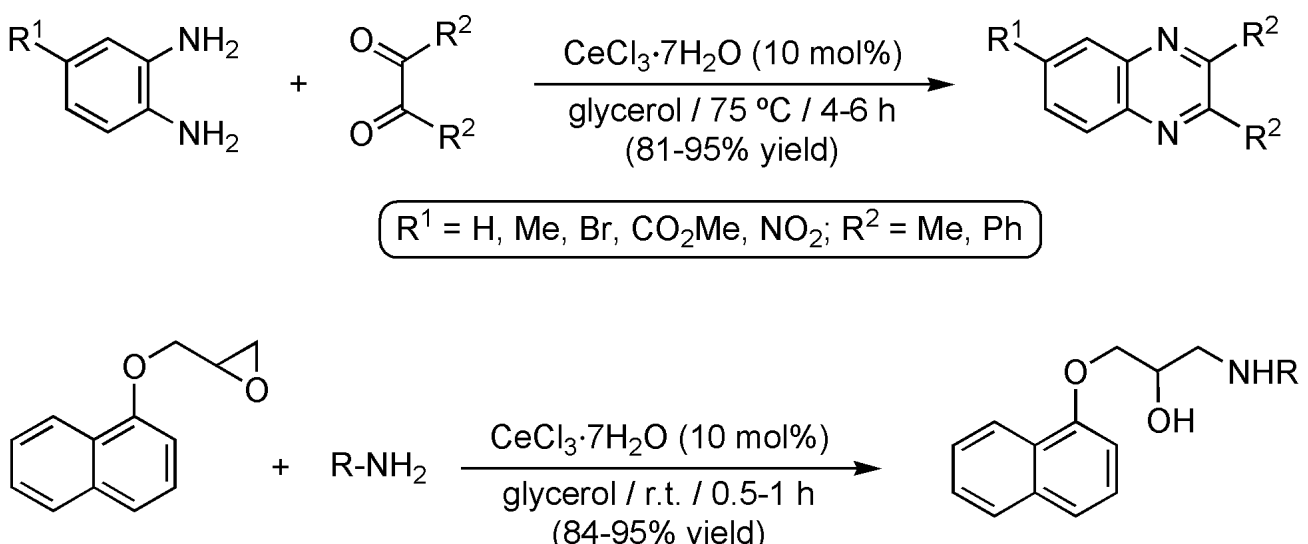

$$
\mathrm{R}=\mathrm{Ph},{ }^{\mathrm{i}} \mathrm{Pr}, \mathrm{CH}_{2} \mathrm{CH}_{2}-3,4-\mathrm{C}_{6} \mathrm{H}_{3}(\mathrm{OMe})_{2}, \mathrm{C}(=\mathrm{S}) \mathrm{Me}, \mathrm{C}(=\mathrm{S}) \mathrm{Ph}
$$

Scheme 32. Some catalytic transformations promoted by $\mathrm{CeCl}_{3} \cdot 7 \mathrm{H}_{2} \mathrm{O}$ in glycerol.

Glycerol combined with zinc(II) acetate was employed by Dos Santos and co-workers to catalyze the coupling of 2-cyanopyridine with 2-amino alcohols (Scheme 33) [98]. The reactions, performed under MW irradiation, delivered the corresponding 2-pyridyl-2oxazolines 39 in moderate to good yields, and without epimerization when enantiopure amino alcohols were used as substrates. Once the reaction finished, isolation of $\mathbf{3 9}$ was easily accomplished by extraction with ethyl acetate, and the glycerol/zinc(II) acetate catalytic system could be recycled four times, albeit with partial loss of activity after each run.
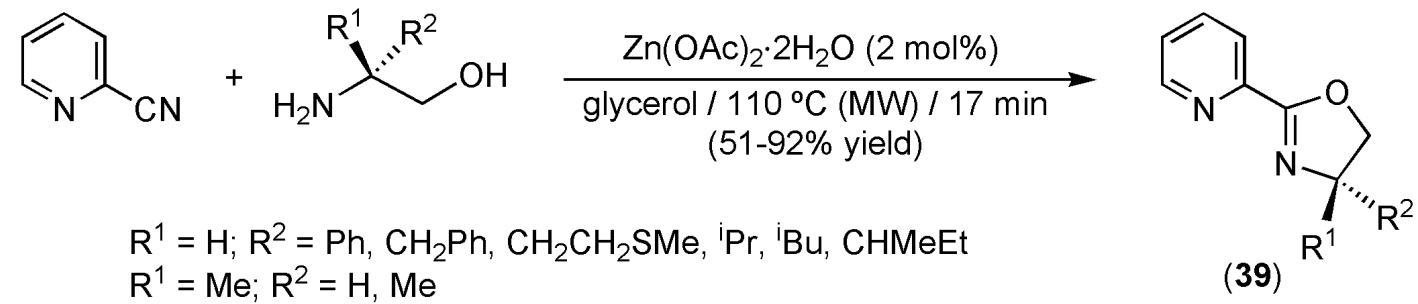

Scheme 33. Zn(II)-catalyzed synthesis of 2-pyridyl-2-oxazolines in glycerol.

Finally, polymerization of pyrrole catalyzed by ferric chloride and sodium $p$ toluenesulfonate has been very recently studied using glycerol as solvent [99]. Performing 
the reaction at $0 \stackrel{\circ}{ } \mathrm{C}$, electronic conducting polypyrrole nanospheres of ca. $60 \mathrm{~nm}$, a size 5-6 times lower than that of the polypyrrole commonly synthesized in water, were obtained. Remarkably, the charge storage capability of this nanosized material was superior to that of conventional polypyrrole, due to its small particle size, higher surface area and more appropriate pore size distribution. The authors proposed that glycerol plays a key role in tailoring the nanostructure during polymerization, controlling also the polypyrrole particles size as a stabilizer.

\section{Biocatalysis}

Water is undoubtedly the preferred solvent for biocatalysis, but the hydrophobic character of many organic molecules, the occurrence of undesired side reactions such as hydrolysis, and the difficulties associated with the separation of the products are major drawbacks in the field. Despite their negative environmental impact, organic solvents are usually employed to circumvent these problems. In 2006, Wolfson and co-workers demonstrated that glycerol is a suitable green reaction medium to perform organic biotransformations, accomplishing successfully the asymmetric reduction of methyl acetoacetate by means of free (FBY) and immobilized (IBY; alginate beads) baker's yeast [100]. Since then, other biotransformations were conveniently performed in glycerol as already indicated in our previous review article published in 2011 [31]. In the most recent years covered herein, Wolfon's group used the asymmetric reduction of ethyl acetoacetate to compare how yeast cell viability, reaction performances and product extraction yields are affected in different glycerol-derived solvents and water (some representative data are shown in Scheme 34) $[38,101]$. The results obtained pointed out that, while water is preferable in terms of viability and activity, the glycerol-based solvents allows a more effective separation of the reaction product (five extracting organic solvents of different polarity were screened and with all of them extraction yields were lower when water was employed as the reaction medium). 


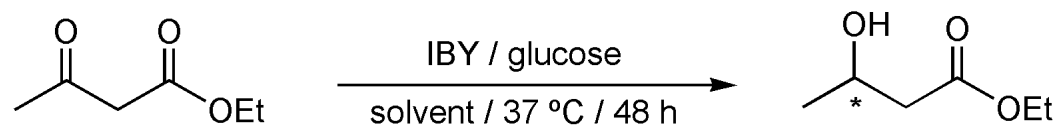

\begin{tabular}{lll} 
Solvent & Conv. & ee \\
\hline water & $74 \%$ & $>99 \%$ \\
glycerol & $45 \%$ & $>99 \%$ \\
glycerol triacetate & $52 \%$ & $97 \%$ \\
glycerol tributyrate & $50 \%$ & $98 \%$
\end{tabular}

Scheme 34. Asymmetric reduction of ethyl acetoacetate catalyzed by Baker's yeast in different solvents.

In an independent report, Sharma and co-workers performed successfully the reduction of 2-tert-butylcyclohexanone, 4-tert-butylcyclohexanone and 4-ethylcyclohexanone by means of both free (FBY) and immobilized (IBY; polyacrylamide) baker's yeast in glycerol [102]. The use of IBY resulted in slightly higher yields (84-87\% vs $79-82 \%$ after $72 \mathrm{~h}$ at r.t.) and facilitated the isolation of the resulting cyclohexanol products. Asymmetric reduction of the $\alpha$-chloroacetophenone $\mathbf{4 0}$ in glycerol, with a cultured whole-cell biocatalyst of the yeast Williopsis californica, was also developed by Sugai and co-workers in their synthetic approach to $(R)$-terbutaline hydrochloride 41 , a potent $\beta_{2}$-adrenoceptor-stimulating agent (Scheme 35) [103].<smiles>COc1cc(OC)cc(C(=O)CCl)c1</smiles>

Scheme 35. Biocatalytic asymmetric reduction of $\mathbf{4 0}$ in the route to $(R)$-terbutaline hydrochloride 41.

In addition to these reduction processes, glycerol was shown to be an excellent alternative for use as a co-solvent in the resolution of racemic phenylethanol with different acylating reagents (vinyl acetate, ethyl acetate, iso-propenyl acetate or acetic anhydride) catalyzed by the Burkholderia cepacia lipase immobilized in ginger starch film [104]. The mixture hexane/glycerol was particularly adequate for such ends. Different biocatalytic 
transformations have also been described employing solvents derived from glycerol (DES, glycerol esters, ethers, etc.) [105-110].

\section{Conclusion}

In brief, all chemistry here presented, along with that already discussed in our previous review article [31], clearly demonstrates the utility of glycerol as green reaction

medium for countless organic transformations. A large number of examples showing improved reaction performances and selectivities, easier product separation and effective catalyst recycling, hallmarks of this green solvent, have appeared during the last two years. The problems associated with its high viscosity have not been an impediment to the development of this research field, which will continue to expand in the coming years due to the great availability and low price of glycerol.

\section{Acknowledgements}

Financial support from the MINECO of Spain (Projects CTQ2010-14796/BQU and CSD2007-00006) is gratefully acknowledged.

\section{Conflict of Interest}

The authors declare no conflict of interest.

\section{References}

[1] Anastas, P.T.; Warner, J.C. In: Green Chemistry: Theory and Practice; Oxford University Press: Oxford, 1998.

[2] Matlack, A.S. In: Introduction to Green Chemistry; Marcel Dekker Inc.: New York, 2001

[3] Handbook of Green Chemistry and Technology; Clark, J.H.; Macquarrie, D.J., Eds.; Blackwell Publishing: Abingdon, 2002. 
[4] Poliakoff, M.; Fitzpatrick, J.M.; Farren, T.R.; Anastas, P.T. Green Chemistry: Science and politics of change. Science, 2002, 297, 807-810.

[5] Sheldon, R.A.; Arends, I.; Hanefeld, U. In: Green Chemistry and Catalysis; Wiley-VCH: Weinheim, 2007.

[6] Lancaster, M. In: Green Chemistry: An Introductory Text; RSC Publishing: Cambridge, 2010.

[7] Green Chemistry in the Pharmaceutical Industry; Dunn, P.J.; Wells, A.S.; Williams, M.T., Eds.; Wiley-VCH: Weinheim, 2010.

[8] Green Chemistry for Environmental Sustainability; Sharma, S.K.; Mudhoo, A., Eds.; CRC Press: Boca Raton, 2011.

[9] Innovations in Green Chemistry and Green Engineering; Anastas, P.T.; Zimmerman, J.B., Eds.; Springer Science+Business Media: New York, 2013.

[10] Constable, D.J.C.; Curzons, A.D.; Cunningham, V.L. Metrics to "green" chemistry Which are the best? Green Chem., 2002, 4, 521-527.

[11] Constable, D.J.C.; Jiménez-González, C.; Henderson, R.K. Perspective on solvent use in the pharmaceutical industry. Org. Process Res. Dev., 2007, 11, 133-137.

[12] Jiménez-González, C.; Poechlauer, P.; Broxterman, Q.B.; Yang, B.-S.; am Ende, D.; Baird, J.; Bertsch, C.; Hannah, R.E.; Dell’Orco, P.; Noorman, H.; Yee, S.; Reintjens, R.; Wells, A.; Massonneau, V.; Manley, J. Key green engineering research areas for sustainable manufacturing: A perspective from pharmaceutical and fine chemicals manufacturers. Org. Process Res. Dev., 2011, 15, 900-911.

[13] Nelson, W.M. In: Green Solvents for Chemistry: Perspectives and Practice; Oxford University Press: New York, 2003.

[14] Clark, J.H.; Taverner, S.J. Alternative solvents: Shades of green. Org. Process Res. Dev., 2007, 11, 149-155.

[15] Kerton, F.M. In: Alternative Solvents for Green Chemistry; RSC Publishing: Cambridge, 2009. 
[16] Li, C.-J.; Chan, T.H. In: Comprehensive Organic Reactions in Aqueous Media; John Wiley \& Sons: Hoboken, 2007.

[17] Organic Reactions in Water: Principles, Strategies and Applications; Lindstrom, U.M., Ed.; Blackwell Publishing Ltd.: Oxford, 2007.

[18] Handbook of Green Chemistry (vol. 5); Anastas P.T.; Li, C.-J., Eds.; Wiley-VCH: Weinheim, 2010.

[19] Water in Organic Synthesis; Kobayashi, S., Ed.; Thieme-Verlag: Stuttgart, 2012.

[20] Aqueous-Phase Organometallic Catalysis: Concepts and Applications; Cornils, B.; Herrmann, W.A., Eds.; Wiley-VCH: Weinheim, 1998.

[21] Joó, F. In: Aqueous Organometallic Catalysis; Kluver: Dordrecht, 2001.

[22] Metal-Catalyzed Reactions in Water; Dixneuf P.H.; Cadierno, V., Eds.; Wiley-VCH: Weinheim, 2013.

[23] Horváth, I.T. Solvents from nature. Green Chem., 2008, 10, 1024-1028.

[24] Pace, V.; Hoyos, P.; Castoldi, L.; Domínguez de María, P.; Alcántara, A. R. 2Methyltetrahydrofuran (2-MeTHF): A biomass-derived solvent with broad application in organic chemistry. ChemSusChem, 2012, 5, 1369-1379.

[25] Yang, J.; Tan, J.-N.; Gu, Y. Lactic acid as an invaluable bio-based solvent for organic reactions. Green Chem., 2012, 14, 3304-3317.

[26] Alonso, D.M.; Wettstein, S.G.; Dumesic, J.A. Gamma-valerolactone, a sustainable platform molecule derived from lignocellulosic biomass. Green Chem., 2013, 15, 584595.

[27] Zhou, C.-H.; Beltramini, J.N.; Fan, Y.-X.; Lu, G.Q. Chemoselective catalytic conversion of glycerol as a biorenewable source to valuable commodity chemicals. Chem. Soc. Rev., 2008, 37, 527-549.

[28] Pagliaro, M.; Rossi, M. The Future of Glycerol: New Usages for a Versatile Raw Material; RSC Publishing: Cambridge, 2010.

[29] Gu, Y.; Barrault, J.; Jérôme, F. Glycerol as an efficient promoting medium for organic reactions. Adv. Synth. Catal., 2008, 350, 2007-2012. 
[30] Gu, Y.; Jérôme, F. Glycerol as a sustainable solvent for green chemistry. Green Chem., 2010, 12, 1127-1138.

[31] Díaz-Álvarez, A.E.; Francos, J.; Lastra-Barreira, B.; Crochet, P.; Cadierno, V. Glycerol and derived solvents: new sustainable reaction media for organic synthesis. Chem. Commun., 2011, 47, 6208-6227.

[32] Wolfson, A.; Dlugy, C.; Tavor, D. Glycerol-based solvents in organic synthesis. Trends Org. Chem., 2011, 15, 41-50.

[33] Wolfson, A.; Dlugy, C.; Tavor, D. In: Homogeneous Catalysts: Types, Reactions and Applications; Poehler, A.C., Ed.; Nova Science Publishers: New York, 2011, pp. 185203.

[34] Wolfson, A.; Tavor, D.; Cravotto, G. In: Glycerol: Production, Structure and Applications; Silva, M.D.S.; Ferreira, P.C., Eds.; Nova Science Publishers: New York, 2012, pp. 233-248.

[35] Calvino-Casilda, V. In: Green Solvents I: Properties and Applications in Chemistry; Mohammad, A.; Inamuddin, Eds.; Springer: Dordrecht, 2012, pp. 187-207.

[36] Wolfson, A.; Dlugy, C.; Shotland, Y. Glycerol as a green solvent for high product yields and selectivities. Environ. Chem. Lett., 2007, 5, 67-71.

[37] Wolfson, A.; Kimchi, H.; Tavor, D. Nucleophilic substitution of benzyl halides with ammonium acetate in presence of glycerol as green solvent. Asian J. Chem., 2011, 23, $1227-1229$.

[38] Wolfson, A.; Snezhko, A.; Meyouhas, T.; Tavor, D. Glycerol derivatives as green reaction mediums. Green Chem. Lett. Rev., 2012, 5, 7-12.

[39] Wolfson, A.; Azran, E.; Dlugy, C.; Tavor, D. Base catalyzed glycerolysis of benzyl acetate. Lett. Org. Chem., 2011, 8, 504-508.

[40] Kore, P.P.; Kachare, S.D.; Kshirsagar, S.S.; Oswal, R.J. Base catalyzed glycerolysis of ethyl acetate. Organic Chem. Curr. Res., 2012, 1, 108.

[41] Wolfson, A.; Naim, S.; Dlugy, C.; Tavor, D. Acid catalysed transesterification of benzyl acetate in glycerol. Chim. Oggi, 2012, 30, 69-71. 
[42] Cabrera, D.M.L.; Líbero, F.M.; Alves, D.; Perin, G.; Lenardão, E.J.; Jacob, R.G. Glycerol as a recyclable solvent in the microwave-assisted synthesis of disulfides. Green Chem. Lett. Rev., 2012, 5, 329-336.

[43] Thurow, S.; Webber, R.; Perin, G.; Lenardão, E.J.; Alves, D. Glycerol/hypophosphorous acid: An efficient system solvent-reducing agent for the synthesis of 2-organylselanyl pyridines. Tetrahedron Lett., 2013, 54, 3215-3218.

[44] Ying, A.; Zhang, Q.; Li, H.; Shen, G.; Gong, W.; He, M. An environmentally benign protocol: catalyst-free Michael addition of aromatic amines to $\alpha, \beta$-unsaturated ketones in glycerol. Res. Chem. Intermed., 2013, 39, 517-525.

[45] Sadek, K.U.; Mekheimer, R.A.; Hameed, A.M.A.; Elnahas, F.; Elnagdi, M.H. Green and highly efficient synthesis of 2-arylbenzothiazoles using glycerol without catalyst at ambient temperature. Molecules, 2012, 17, 6011-6019.

[46] Zhang, X.-Z.; Zhuo, W.-J.; Yang, M.; Wang, J.-X.; Bai, L. Microwave-assisted synthesis of benzothiazole derivatives using glycerol as green solvent. J. Chem. Res., 2012, 36, 489-491.

[47] Nascimento, J.E.R.; Barcellos, A.M.; Sachini, M.; Perin, G.; Lenardão, E.J.; Alves, D.; Jacob, R.G.; Missau, F. Catalyst-free synthesis of octahydroacridines using glycerol as recyclable solvent. Tetrahedron Lett., 2011, 52, 2571-2574.

[48] Radatz, C.S.; Silva, R.B.; Perin, G.; Lenardão, E.J.; Jacob, R.G.; Alves, D. Catalystfree synthesis of benzodiazepines and benzimidazoles using glycerol as recyclable solvent. Tetrahedron Lett., 2011, 52, 4132-4136.

[49] Kumar, T.A.; Devi, B.R.; Dubey, P.K. Simple, facile and complete green synthesis of N-alkyl-2-styrylbenzimidazoles using glycerol and PEG-600 as green solvents. Der Chemica Sinica, 2013, 4, 116-121.

[50] Bachhav, H.M.; Bhagat, S.B.; Telvekar, V.N. Efficient protocol for the synthesis of quinaxoline, benzoxazole and benzimidazole derivatives using glycerol as green solvent. Tetrahedron Lett., 2011, 52, 5697-5701. 
[51] Jagrut, V.B.; Lingampalle, D.L.; Netankar, P.D.; Jadhav, W.N. Glycerol mediated safer synthetic route of pyrazoles bearing quinolino and benzene sulfonamido pharmacophores. Der Pharma Chemica, 2013, 5, 8-11.

[52] Deligeorgiev, T.; Gadjev, N.; Kaloyanova, S.; Lesev, N.; Vasilev, A.; Alexiev, A. A novel general method for fast and easy preparation of cationic, neutral dimethinehemicyanine and dimethine dyes by uncatalysed Knoevenagel condensation. Color Technol., 2012, 128, 417-424.

[53] Narsaiah, A.V.; Ghogare, R.S.; Biradar, D.O. Glycerin as alternative solvent for the synthesis of thiazoles. Org. Commun., 2011, 4, 75-81.

[54] Deligeorgiev, T.; Kaloyanova, S.; Lesev, N.; Alajarín, R.; Vaquero, J.J.; Álvarez-Builla, J. An environmentally benign synthesis of 2-cyanomethyl-4-phenylthiazoles under focused microwave irradiation. Green Sustainable Chem., 2011, 1, 170-175.

[55] Deligeorgiev, T.; Kaloyanova, S.S.; Lesev, N.Y.; Vaquero, J.J. An environmentally benign procedure for the synthesis of substituted 2-thiobenzothiazoles, 2thiobenzoxazoles, 2-thiobenzimidazoles, and 1,3-oxazolopyridine-2-thiols. Monatsh. Chem., 2011, 142, 895-899.

[56] Lobo, H. R.; Singh, B. S.; Shankarling, G. S. Deep eutectic solvents and glycerol: a simple, environmentally benign and efficient catalyst/reaction media for synthesis of $N$ aryl phthalimide derivatives. Green Chem. Lett. Rev., 2012, 5, 487-533.

[57] Nandre, K.P.; Salunke, J.K.; Nandre, J.P.; Patil, V.S.; Borse, A.U.; Bhosale, S.V. Glycerol mediated synthesis of 5 -substituted $1 \mathrm{H}$-tetrazole under catalyst free conditions. Chin. Chem. Lett., 2012, 23, 161-164.

[58] Gu Y. Multicomponent reactions in unconventional solvents: state of the art. Green Chem., 2012, 14, 2091-2128.

[59] Kumar, A.; Kumar, M.; Gupta, M.K.; Gupta, L.P. A catalyst-free C-H hydroarylation of coumarin derived ortho-quinone methide (o-QM) with electron rich arenes in glycerol. RSC Adv., 2012, 2, 8277-8280. 
[60] Safaei, H.R.; Shekouhy, M.; Rahmanpur, S.; Shirinfeshan, A. Glycerol as a biodegradable and reusable promoting medium for the catalyst-free one-pot three component synthesis of $4 H$-pyrans. Green Chem., 2012, 14, 1696-1704.

[61] Somwanshi, J.L.; Shinde, N.D.; Faruqui, M. Catalyst-free synthesis of furano- and pyranoquinolines by using glycerol as recyclable solvent. Heterocycl. Lett., 2013, 3, 69-74.

[62] Nemati, F.; Hosseini, M.M.; Kiani, H. Glycerol as a green solvent for efficient, one-pot and catalyst free synthesis of 2,4,5-triaryl and 1,2,4,5-tetraaryl imidazole derivatives. $J$. Saudi Chem. Soc., 2013, in press (http://dx.doi.org/10.1016/j.jscs.2013.02.004).

[63] Quan, Z.-J.; Ren, R.-G.; Da, Y.-X.; Zhang, Z.; Wang, X.-C. Glycerol as an alternative green reaction medium for multicomponent reactions using $\mathrm{PS}-\mathrm{PEG}-\mathrm{OSO}_{3} \mathrm{H}$ as catalyst. Synth. Commun., 2011, 41, 3106-3116.

[64] Konyushenko, E.N.; Reynaud, S.; Pellerin, V.; Trchová, M.; Stejskal, J.; Sapurina, I. Polyaniline prepared in ethylene glycol or glycerol. Polymer, 2011, 52, 1900-1907.

[65] Wolfson, A.; Dlugy, C. Palladium-catalyzed Heck and Suzuki coupling in glycerol. Chem. Pap., 2007, 61, 228-232.

[66] Cravotto, G.; Orio, L.; Gaudino, E.C.; Martina, K.; Tavor, D.; Wolfson, A. Efficient synthetic protocols in glycerol under heterogeneous catalysis. ChemSusChem, 2011, $4,1130-1134$.

[67] Azua, A.; Mata, J.A.; Heymes, P.; Peris, E.; Lamaty, F.; Martinez, J.; Colacino, E. Palladium N-heterocyclic carbene catalysts for the ultrasound-promoted SuzukiMiyaura reaction in glycerol. Adv. Synth. Catal., 2013, 355, 1107-1116.

[68] Banik, B.; Tairai, A.; Shahnaz, N.; Das, P. Palladium(II) complex with a potential $\mathrm{N}_{4^{-}}$ type Schiff-base ligand as highly efficient catalyst for Suzuki-Miyaura reactions in aqueous media. Tetrahedron Lett., 2012, 53, 5627-5630.

[69] Cintas, P.; Cravotto, G.; Gaudino, E.C.; Orio, L.; Boffa, L. Reticulated Pd(II)/Cu(I) cyclodextrin complexes as recyclable green catalyst for Sonogashira alkynylation. Catal. Sci. Technol., 2012, 2, 85-87. 
[70] Khatri, P.K.; Jain, S.L. Glycerol ingrained copper: An efficient recyclable catalyst for the N-arylation of amines with aryl halides. Tetrahedron Lett., 2013, 54, 2740-2743.

[71] Gonçalves, L.C.; Fiss, G.F.; Perin, G.; Alves, D.; Jacob, R.G.; Lenardão, E.J. Glycerol as a promoting medium for cross-coupling reactions of diaryl diselenides with vinyl bromides. Tetrahedron Lett., 2010, 51, 6772-6775.

[72] Ricordi, V.G.; Freitas, C.S.; Perin, G.; Lenardão, E.J.; Jacob, R.G.; Savegnano, L.; Alves, D. Glycerol as a recyclable solvent for copper-catalyzed cross-coupling reactions of diaryl diselenides with aryl boronic acids. Green Chem., 2012, 14, 10301034.

[73] Farnetti, E.; Kašpar, J.; Crotti, C. A novel glycerol valorization route: Chemoselective dehydrogenation catalyzed by iridium derivatives. Green Chem., 2009, 11, 704-709.

[74] Wolfson, A.; Dlugy, C.; Shotland, Y.; Tavor, D. Glycerol as solvent and hydrogen donor in transfer hydrogenation-dehydrogenation reactions. Tetrahedron Lett., 2009, 50, $5951-5953$.

[75] Díaz-Álvarez, A.E.; Cadierno, V. Glycerol: A promising green solvent and reducing agent for metal-catalyzed transfer hydrogenation reactions and nanoparticles formation. Appl. Sci., 2013, 3, 55-69.

[76] Azua, A.; Mata, J.A.; Peris, E. Iridium NHC based catalysts for transfer hydrogenation processes using glycerol as solvent and hydrogen donor. Organometallics, 2011, 30, $5532-5536$.

[77] Azua, A.; Mata, J.A.; Peris, E.; Lamaty, F.; Martinez, J.; Colacino, E. Alternative energy input for transfer hydrogenation using iridium NHC based catalysts in glycerol as hydrogen donor and solvent. Organometallics, 2012, 31, 3911-3919.

[78] Díaz-Álvarez, A.E.; Crochet, P.; Cadierno, V. Ruthenium-catalyzed reduction of allylic alcohols using glycerol as solvent and hydrogen donor. Catal. Commun., 2011, 13, 9196. 
[79] Cadierno, V.; Francos, J.; Gimeno, J.; Nebra N. Ruthenium-catalyzed reduction of allylic alcohols: An efficient isomerization/transfer hydrogenation tandem process. Chem. Commun., 2007, 2536-2538.

[80] Cadierno, V.; Crochet, P.; Francos, J.; García-Garrido, S.E.; Gimeno, J.; Nebra N. Ruthenium-catalyzed isomerization/transfer hydrogenation in organic and aqueous media: A one-pot tandem process for the reduction of allylic alcohols. Green Chem., 2009, 11, 1992-2000.

[81] Wu, R.; Beauchamps, M.G.; Laquidara, J.M.; Sowa Jr., J.R. Ruthenium-catalyzed asymmetric transfer hydrogenation of allylic alcohols by an enantioselective isomerization/transfer hydrogenation mechanism. Angew. Chem. Int. Ed., 2012, 51, 2106-2110.

[82] Vidal, C.; Suárez, F.J.; García-Álvarez, J. Deep Eutectic Solvents (DES) as green reaction media for the redox isomerization of allylic alcohols into carbonyl compounds catalyzed by the ruthenium complex $\left[\mathrm{RuCl}_{2}\left(\eta^{3}: \eta^{3}-\mathrm{C}_{10} \mathrm{H}_{16}\right)\right.$ (benzimidazole)]. Catal. Commun., 2013, in press (http://dx.doi.org/10.1016/j.catcom.2013.04.002).

[83] Díaz, G.C.; Perez, R.S.; Tapanes, N.C.O.; Aranda, D.A.G.; Arceo, A.A. Hydrolysishydrogenation of soybean oil and tallow. Nat. Sci., 2011, 3, 530-534.

[84] Tavor, D.; Gefen, I.; Dlugy, C.; Wolfson, A. Transfer hydrogenations of nitrobenzene using glycerol as solvent and hydrogen donor. Synth. Commun., 2011, 41, 3409-3416.

[85] Gawande, M.B.; Rathi, A.K.; Branco, P.S.; Nogueira, I.D.; Velhinho, A.; Shrikhande, J.J.; Indulkar, U.U.; Jayaram, R.V.; Ghumman, C.A.A.; Bundaleski, N.; Teodoro, O.M.N.D. Regio- and chemoselective reduction of nitroarenes and carbonyl compounds over recyclable magnetic ferrite-nickel nanoparticles $\left(\mathrm{Fe}_{3} \mathrm{O}_{4}-\mathrm{Ni}\right)$ by using glycerol as a hydrogen source. Chem. Eur. J., 2012, 18, 12628-12632.

[86] Cui, X.; Deng, Y.; Shi, F. Reductive N-alkylation of nitro compounds to $\mathrm{N}$-alkyl and N,N-dialkyl amines with glycerol as the hydrogen source. ACS Catal., 2013, 3, 808811. 
[87] Chung, W.J.; Baskar, C.; Chung, D.G.; Han, M.D.; Lee, C.H. Catalytic transfer hydrogenation of carboxylic acids to their corresponding alcohols by using glycerol as hydrogen donor. Republic Korean Kongkae Taeho Kongbo, KR 2012006276, 2012.

[88] Dibenedetto, A.; Stufano, P.; Nocito, F.; Aresta, M. Ru"-mediated hydrogen transfer from aqueous glycerol to $\mathrm{CO}_{2}$ : From waste to value-added products. ChemSusChem, 2011, 4, 1311-1315.

[89] Sanz, A.; Azua, A.; Peris, E. "( $\eta^{6}$-arene)Ru(bis-NHC)" complexes for the reduction of $\mathrm{CO}_{2}$ to formate with hydrogen and by transfer hydrogenation with iPrOH. Organometallics, 2010, 39, 6339-6343.

[90] Toledano, A.; Serrano, L.; Labidi, J.; Pineda, A.; Balu, A.M.; Luque, R. Heterogeneously catalysed mild hydrogenolytic depolymerisation of lignin under microwave irradiation with hydrogen-donating solvents. ChemCatChem, 2013, 5, 977985.

[91] Verendel J.J.; Nordlund, M.; Andersson, P.G. Selective metal-catalyzed transfer of $\mathrm{H}_{2}$ and CO from polyols to alkenes. ChemSusChem, 2013, 6, 426-429.

[92] García, N.; García-García, P.; Fernández-Rodríguez, M.A.; García, D.; Pedrosa, M.R.; Arnáiz, F.J.; Sanz, R. An unprecedented use for glycerol: Chemoselective reducing agent for sulfoxides. Green Chem., 2013, 15, 999-1005.

[93] Behbahani, F.K.; Sasani, M. Facile synthesis of bis(indolyl)methanes using iron(III) phosphate. J. Serb. Chem. Soc., 2012, 77, 1157-1163.

[94] He, F.; Li, P.; Gu, Y.; Li, G. Glycerol as a promoting medium for electrophilic activation of aldehydes: Catalyst-free synthesis of di(indolyl)methanes, xanthene-1,8(2H)-diones and 1-oxo-hexahydroxanthenes. Green Chem., 2009, 11, 1767-1773.

[95] Silveira, C.C.; Mendes, S.R.; Líbero, F.M.; Lenard ão, E.J.; Perin, G. Glycerin and $\mathrm{CeCl}_{3} \cdot 7 \mathrm{H}_{2} \mathrm{O}$ : A new recyclable medium for the synthesis of bis(indolyl)methanes. Tetrahedron Lett., 2009, 50, 6060-6063. 
[96] Narsaiah, A.V.; Kumar, J.K. Glycerin and $\mathrm{CeCl}_{3} \cdot 7 \mathrm{H}_{2} \mathrm{O}$ : A new and efficient recyclable reaction medium for the synthesis of quinoxalines. Synth. Commun., 2012, 42, 883892.

[97] Narsaiah, A.V.; Wadavrao, S.B.; Reddy, A.R.; Yadav, J.S. Glycerin and $\mathrm{CeCl}_{3} \cdot 7 \mathrm{H}_{2} \mathrm{O}$ : An efficient and recyclable reaction medium for the ring opening of epoxides with thioamides and amines. Synthesis, 2011, 485-489.

[98] Carmona, R.C.; Schevciw, E.P.; Petrarca de Albuquerque, J.L.; Wendler, E.P.; Dos Santos A.A. Joint use of microwave and glycerol-zinc(II) acetate catalytic system in the synthesis of 2-pyridyl-2-oxazolines. Green Process Synth., 2013, 2, 35-42.

[99] Ghamouss, F.; Brugère, A.; Anbalagan, A.C.; Schmaltz, B.; Luais, E.; Tran-Van, F. Novel glycerol assisted synthesis of polypyrrole nanospheres and its electrochemical properties. Synth. Metals, 2013, 168, 9-15.

[100] Wolfson, A.; Dlugy, C.; Tavor, D.; Blumenfeld, J.; Shotland, Y. Baker's yeast catalyzed asymmetric reduction in glycerol. Tetrahedron: Asymmetry, 2006, 17, 2043-2045.

[101] Wolfson, A.; Dlugy, C.; Tavor, D. Baker's yeast catalyzed asymmetric reduction of prochiral ketones in different reaction mediums. Org. Commun., 2013, 6, 1-11.

[102] Sharma, A.; Ojha, P.; Verma, P.S.; Sharma, I.K. Biocatalytic reduction of selected cyclohexanones. Int. J. ChemTech Res., 2011, 3, 1835-1839.

[103] Taketomi, S.; Asano, M.; Higashi, T.; Shoji, M.; Sugai, T. Chemo-enzymatic route for $(R)$-terbutaline hydrochloride based on microbial asymmetric reduction of a substituted a-chloroacetophenone derivative. J. Mol. Catal. B: Enzym., 2012, 84, 83-88.

[104] Hoffmann, I.; Silva, V.D.; Nascimento, M.G. Enantioselective resolution of $(R, S)-1$ phenylethanol catalyzed by lipases immobilized in starch films. J. Braz. Chem. Soc., 2011, 22, 1559-1567.

[105] Pérez-Sánchez, M.; Sandoval, M.; Cortés-Cabrera, A.; García-Marín, H.; Sinisterra, J.V.; García, J.I.; Hernaiz, M.J. Solvents derived from glycerol modify classical regioselectivity in the enzymatic synthesis of disaccharides with Biolacta $\beta$ galactosidase. Green Chem., 2011, 13, 2810-2817. 
[106] Pérez-Sánchez, Cortés-Cabrera, A.; García-Martín, H.; Sinisterra, J.V.; García, J.I.; Hernaiz, M.J. Improved synthesis of disaccharides with Escherichia coli $\beta$ galactosidase using bio-solvents derived from glycerol. Tetrahedron, 2011, 67, 77087712 .

[107] Zhao, H.; Baker, G.A.; Holmes, S. Protease activation in glycerol-based deep eutectic solvents. J. Mol. Catal. B: Enzym., 2011, 72, 163-167.

[108] Ou, G.; He, B.; Yuan, Y. Lipases are soluble and active in glycerol carbonate as a novel biosolvent. Enzyme Microb. Tech., 2011, 49, 167-170.

[109] Wolfson, A.; Dlugy, C.; Karanet, A.; Tavor, D. A sustainable one-pot synthesis of cinnamyl acetate in triacetin. Tetrahedron Lett., 2012, 53, 4565-4567.

[110] Durand, E.; Lecomte, J.; Baréa, B.; Piombo, G.; Dubreucq, E.; Villeneuve, P. Evaluation of deep eutectic solvents as new media for Candida antarctica B lipase catalyzed reactions. Process Biochem., 2012, 47, 2081-2089. 